US Army Corps of Engineers ${ }_{\circledast}$

Engineer Research and Development Center

Navigation Study for Arthur Kill 50-ft Channel Improvements, New York Harbor

Dennis W. Webb July 2004 


\title{
Navigation Study for Arthur Kill 50-ft Channel Improvements, New York Harbor
}

Dennis W. Webb

Coastal and Hydraulics Laboratory

U.S. Army Engineer Research and Development Center

3909 Halls Ferry Road

Vicksburg, MS 39180-6199

Final report

Approved for public release; distribution is unlimited

\author{
Prepared for U.S. Army Engineer District, New York \\ Jacob K. Javits Federal Building \\ 26 Federal Plaza, Room 2109 \\ New York, NY 10278-0090
}


ABSTRACT: The Arthur Kill Channel is a 13.2-mile segment of the New York and New Jersey Channels along the west side of Staten Island. The reach under consideration for this study extends from Newark Bay to Howland Hook marine terminal, and includes the North of Shooters Island and Elizabethport Reaches. The proposed improvements for this study include deepening of these reaches of the Arthur Kill to $-50 \mathrm{ft}$ mlw to accommodate the post panamax container vessels expected at Howland Hook. Minor widening for the channel alignment was also considered. To evaluate these improvements a real-time ship simulation study was undertaken. Simulation models were developed for both Arthur Kill's present and future conditions. Pilots from New York Harbor operated the simulator as they would in real-life. Based upon these simulations, a final improved channel was developed.

DISCLAIMER: The contents of this report are not to be used for advertising, publication, or promotional purposes. Citation of trade names does not constitute an official endorsement or approval of the use of such commercial products. All product names and trademarks cited are the property of their respective owners. The findings of this report are not to be construed as an official Department of the Army position unless so designated by other authorized documents. 


\section{Contents}

Conversion Factors, Non-SI to SI Units of Measurement...................................

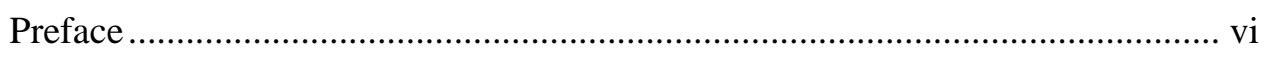

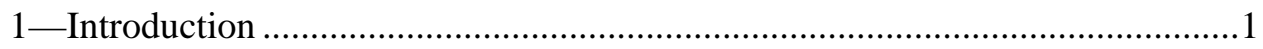

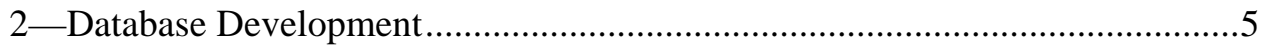

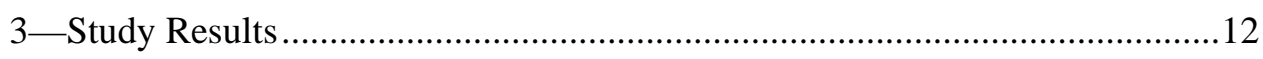

Inbound Container Ship Scenarios.............................................................12

Outbound Container Ship Scenarios ............................................................12

Inbound Tanker Scenarios .......................................................................13

4-Conclusions and Recommendations ..........................................................15

Plates 1-14

Appendix A: Final Questionnaire...................................................................

SF 298

\section{List of Figures}

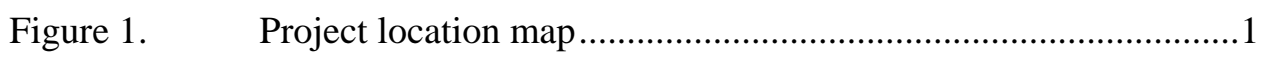

Figure 2. Arthur Kill .........................................................................2

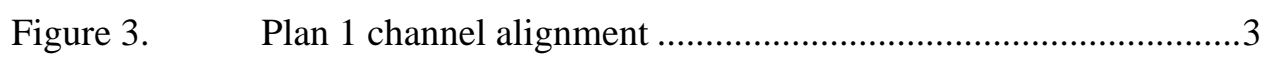

Figure 4. Plan 2 channel alignment ........................................................

Figure 5. Tromso Trust approaching Bayway Bridge................................. $\quad$ Th

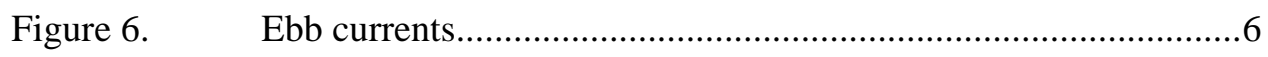

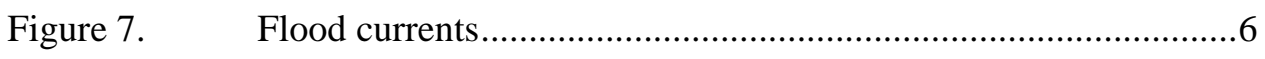

Figure 8. $\quad$ ERDC Ship/Tow Simulator view from tanker, approaching Bayonne Bridge ...................................................

Figure 9. ERDC simulator layout .................................................... 8 
Figure 10. Arrangement of ERDC Ship/Tow Simulator bridge

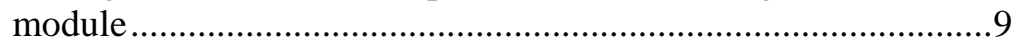

Figure 11. Viewing angle orientation used for backing in Port Jersey Channel.............................................................................10

Figure 12. Rotated bow image on left side of screen.................................11

Figure 13. Rotated stern image on right side of screen .............................11 


\section{Conversion Factors, Non-SI to SI Units of Measurement}

Non-SI units of measurement used in this report can be converted to SI units as follows:

\begin{tabular}{||l|l|l||}
\hline \hline Multiply & By & To Obtain \\
\hline \hline feet & 0.3048 & meters \\
\hline miles (U.S. statute) & 1.609347 & kilometers \\
\hline $\begin{array}{l}\text { horsepower (550 foot-pounds } \\
\text { force per second) }\end{array}$ & 745.6999 & watts \\
\hline
\end{tabular}




\section{Preface}

The model investigation reported herein was authorized by Headquarters, U.S. Army Corps of Engineers at the request of U.S. Army Engineer District, New York, in August 2002. The model experiments were performed during the period October 2003 to November 2003 by personnel of the Coastal and Hydraulics Laboratory (CHL) of the U.S. Army Engineer Research and Development Center (ERDC) under the general supervision of Mr. Thomas. W. Richardson, Director, CHL, and Dr. William D. Martin, Assistant Director, CHL.

The navigation study was performed by Mr. Dennis W. Webb, Deep Draft Navigation Group, and Mr. Donald Wilson, Chief, Navigation Branch, CHL. Visual simulation was developed by Mr. Jeff Montgomery and Mr. Wali Aziz under the general supervision of Mr. Gary Lynch of the Deep Draft Navigation Group. Current modeling was conducted by the Tidal Hydraulics Branch of the Estuary and Hydrosciences Branch, CHL. The report was written by Mr. Webb and reviewed by Mr. Lynch. Ms. Peggy VanNorman of the Navigation Branch, CHL, helped in the preparation of the report.

Acknowledgement is made to Mr. Frank Santangelo of the U.S. Army Engineer District, New York, for his cooperation and assistance at various times throughout the investigation. Special thanks go to Sandy Hook Pilot Association and Metro Pilot Association for access to vessels and for furnishing professional pilots to conduct ship simulator tests on the ERDC Ship/Tow Simulator. Special thanks also go to the independent pilots who participated in the testing program.

COL James R. Rowan, EN, was Commander and Executive Director of ERDC. Dr. James R. Houston was Director. 


\section{Introduction}

New York Harbor waterways are extensively used navigation channels for both commercial and recreational vessels within the Ports of New York and New Jersey. The U.S. Army Corps of Engineers currently maintains about 240 miles of navigation channels within the port (Figure 1). The Arthur Kill Channel is a 13.2 mile segment of the New York and New Jersey Channels along the west side of Staten Inland, which separates Staten Island, NY, from Union and Middlesex Counties, NJ. The reach under consideration for this study extends from Newark Bay, where the Arthur Kill connects with the Kill Van Kull and Newark Bay Channels, 2.4 miles west and south to Howland Hook marine terminal, and includes the North of Shooters Island and Elizabethport Reaches (Figure 2). The proposed improvements for this study include deepening of these reaches of the Arthur Kill to -50 ft mlw to accommodate the post-panamax container vessels expected at Howland Hook.

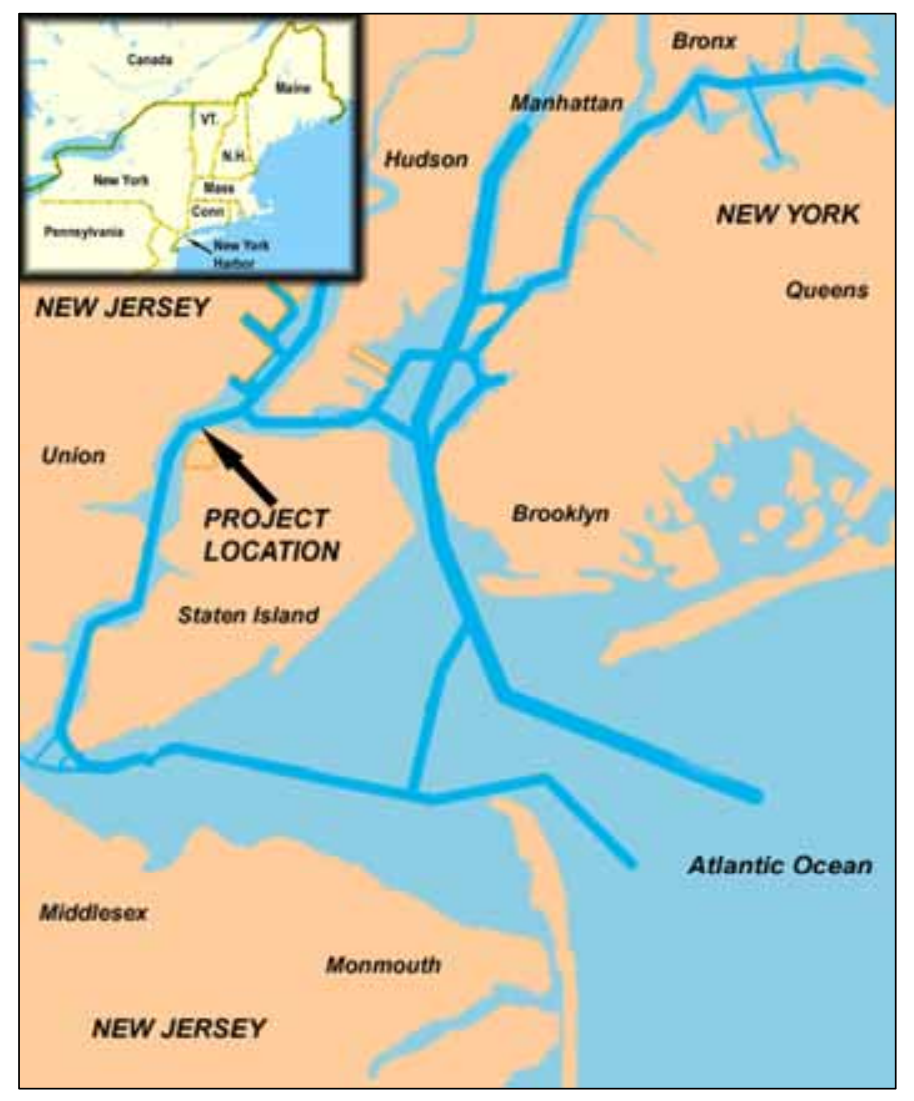

Figure 1. Project location map
Deep-draft traffic in the project reaches are essentially one way, however, in straight portions of the North of Shooters Island Reach, vessels may occasionally pass in accordance with fair tide rules. Typically tanker traffic is inbound only from the Kill Van Kull, with light tankers departing southbound through Raritan Bay. Container ships greater than $700 \mathrm{ft}$ in length bound for Howland Hook marine terminal will normally dock port side to, and back out of port, turn at Bergen Point and proceed outbound through the Kill Van Kull. Shorter container vessels can turn around at the berth.

The Arthur Kill is currently authorized to $-35 \mathrm{ft}$ mlw $(-37 \mathrm{ft}$ mlw in rock), although portions of the channel may be deeper. Container ships typically arrive and depart Howland Hook 


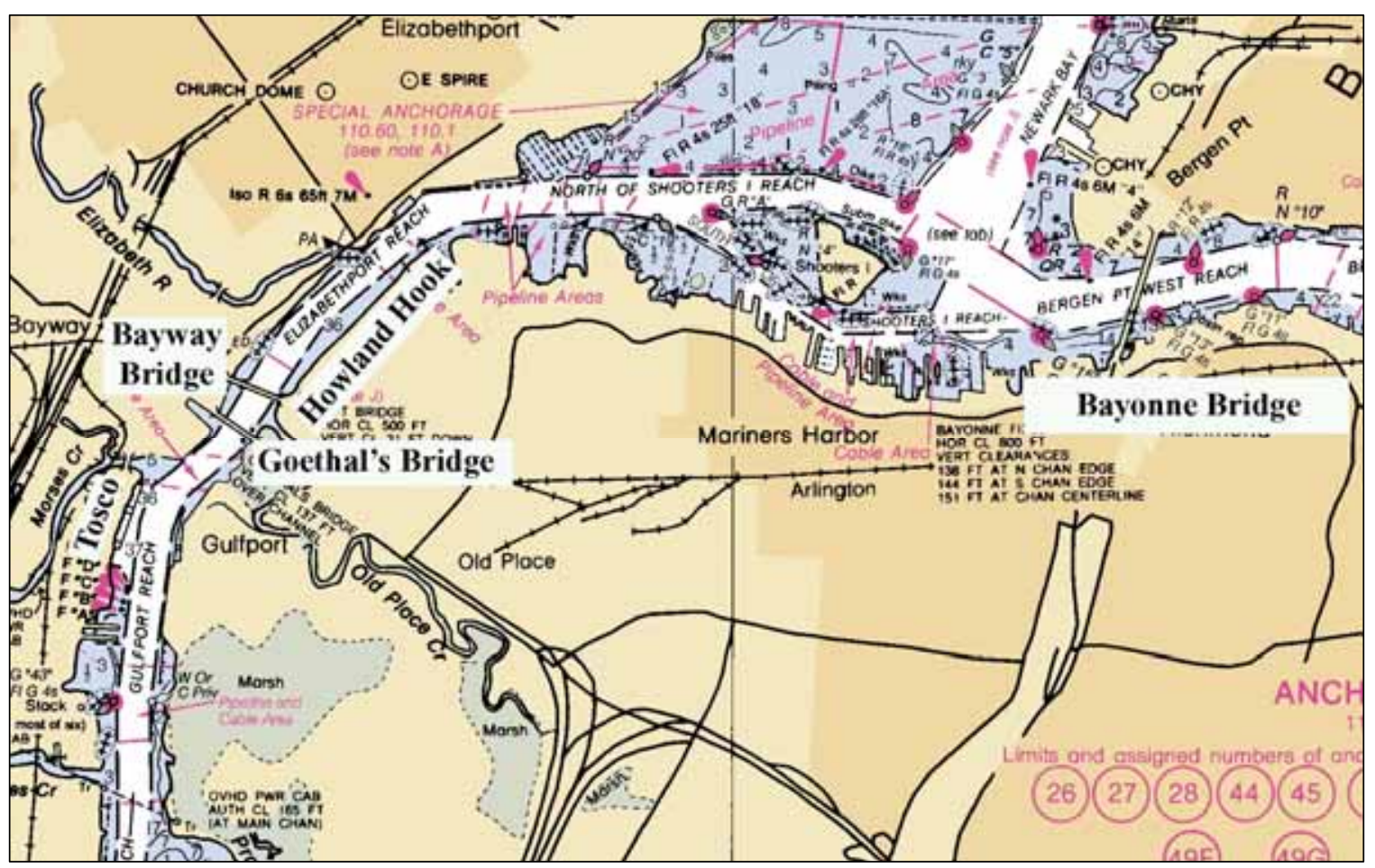

Figure 2. Arthur Kill

loaded to a 33-ft draft. Larger tankers arrive at Tosco around high-water slack tide, drafting $37 \mathrm{ft}$. Once the tankers discharge their product, they depart light loaded, continuing south along the Arthur Kill and exiting through Raritan Bay. An interim project to deepen the Arthur Kill from North of Shooters Island to Howland Hook to $-41 \mathrm{ft} \mathrm{mlw}$, and from Howland Hook to Gulfport to $-40 \mathrm{ft} \mathrm{mlw}$ is scheduled to begin construction within the next year.

The U.S. Army Engineer District, New York, is presently evaluating channel designs to deepen the portion of the Arthur Kill from Newark Bay to Howland Hook to $-50 \mathrm{ft}$ mlw. This will allow fully loaded S-class container ships to call at Howland Hook. The S-class container ships have a length of $1,140 \mathrm{ft}$, a beam of $140 \mathrm{ft}$, and are capable of being loaded to a 47.5-ft draft. The deepening is not on the same channel footprint as the existing channel. The original proposed deepening alignment (Plan 1) is shown in Figure 3. There is a shift in alignment at the eastern end of North of Shooter's Island Reach and widening on the south side of Elizabethport Reach near Howland Hook terminals. During simulations, a modification to the recommended plan was suggested by the pilots. Shown as Plan 2 in Figure 4, this plan is identical to Plan 1, except the north side of the eastern end of North of Shooter's Island Reach is straightened to facilitate the larger container ships backing and turning around at Bergen Point.

The U.S. Army Engineer Research and Development Center (ERDC) conducted a navigation study utilizing real-time ship simulation modeling to evaluate the proposed improvements to Arthur Kill. Model development and on-line testing occurred at the ERDC Coastal and Hydraulics Laboratory (CHL) during the period from June to August 2002. 


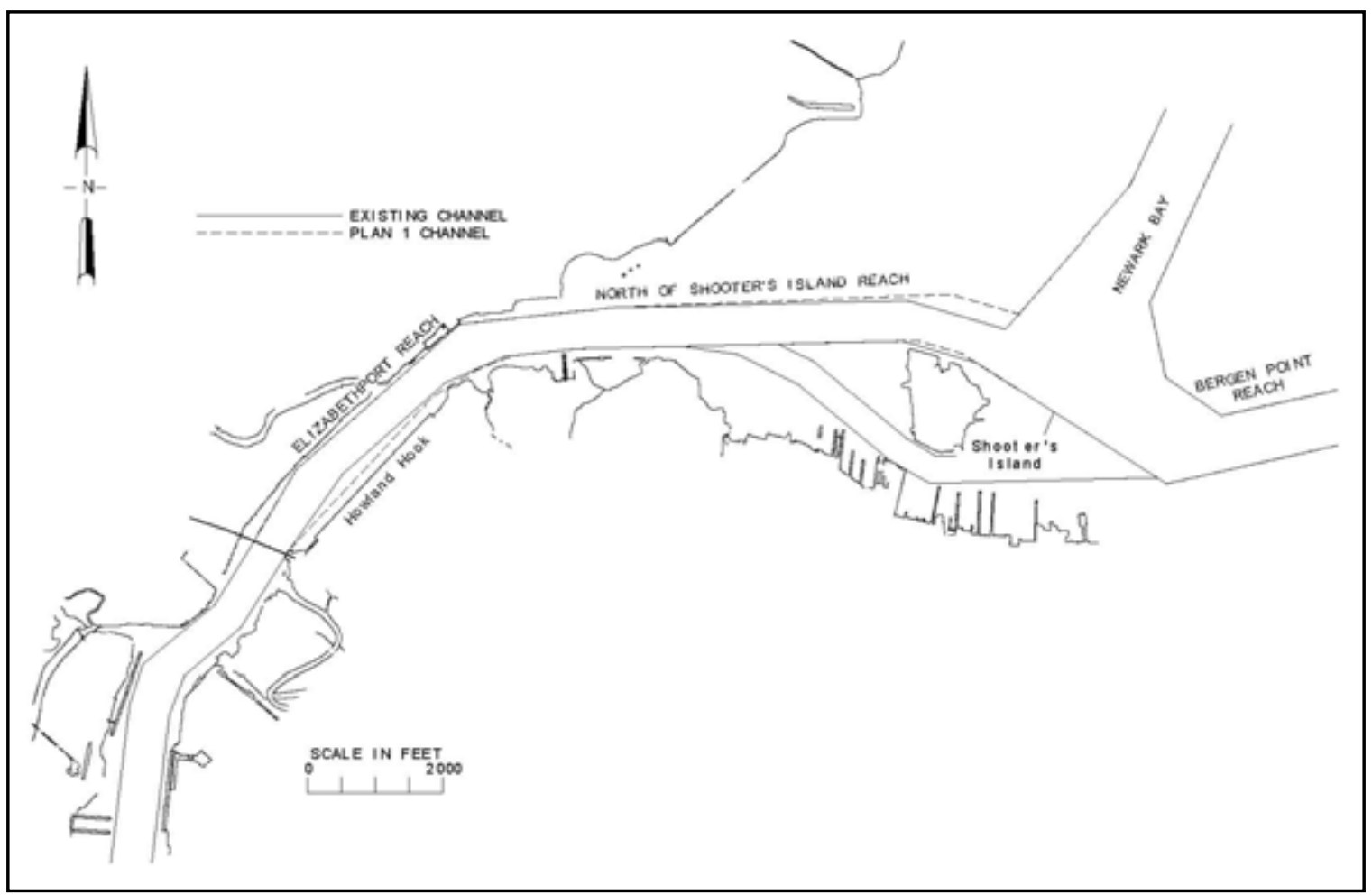

Figure 3. Plan 1 channel alignment

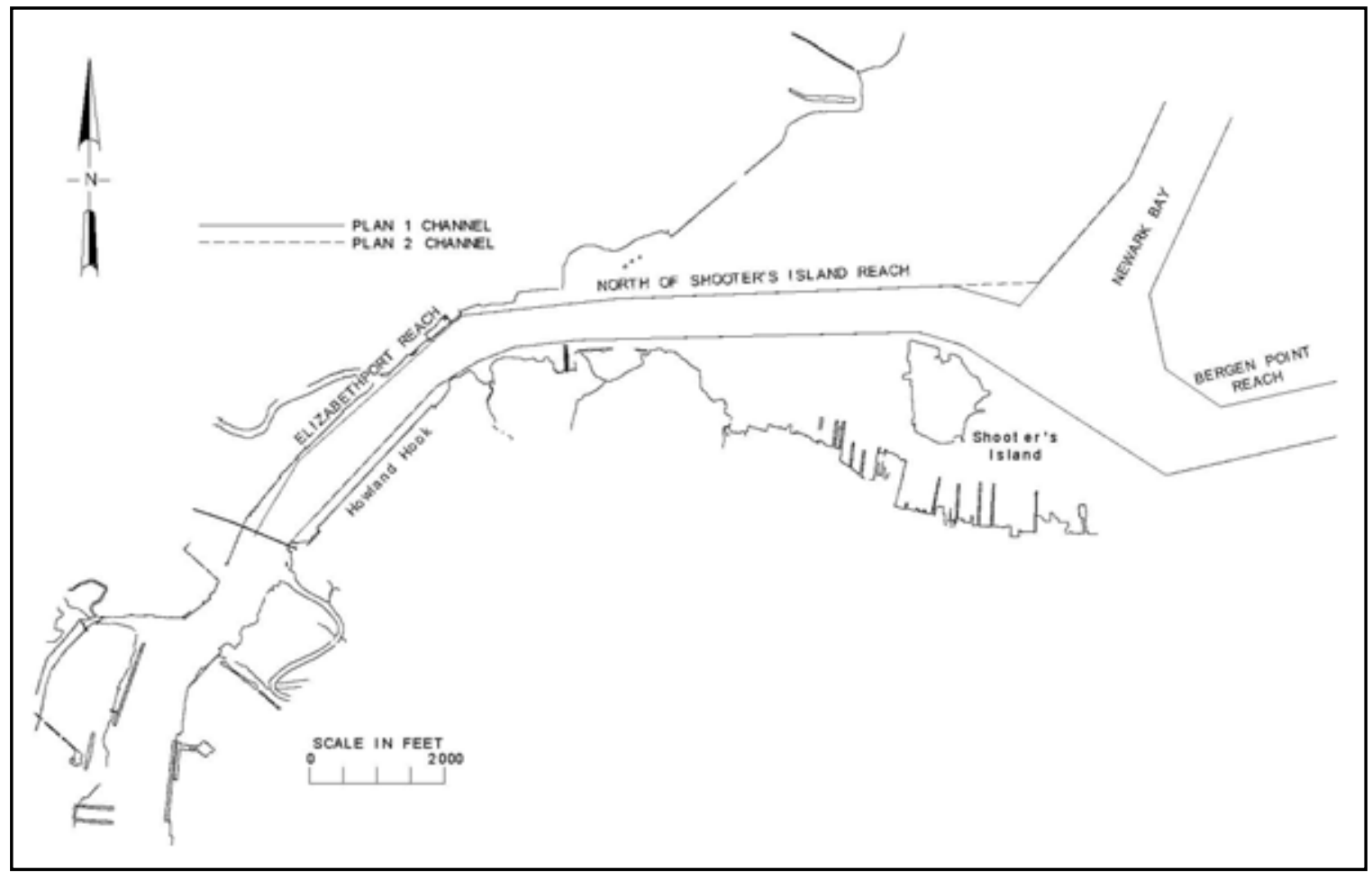

Figure 4. Plan 2 channel alignment 
The reconnaissance trip for Arthur Kill was undertaken April 30 and May 1, 2002. The purpose of the reconnaissance trip was to observe navigation conditions in Arthur Kill. The project site was photographed to update the simulation visual scene.

At approximately 1100 on May 1 representatives of the New York District and ERDC boarded the Tromso Trust west at the Verrazano-Narrows Bridge. The Tromso Trust is an 898-ft-long tanker with a beam of $144 \mathrm{ft}$. The Tromso Trust was loaded to a 37-ft draft. They were accompanied by one New York Harbor pilot and two docking pilots from Moran Towing, Capts. Robert Flannery, Peter Kanenbley, and Dick Reilly. Three video cameras were mounted on the ship. One camera pointed forward, across the bow. The other two pointed perpendicular, one to port and the other starboard. A hand-held Global Positioning System (GPS) was placed on the starboard wing to record the transit. Arrival time at Tosco refinery was approximately 1230. A picture of the Tromso Trust as it approached the Bayway Bridge is shown in Figure 5.

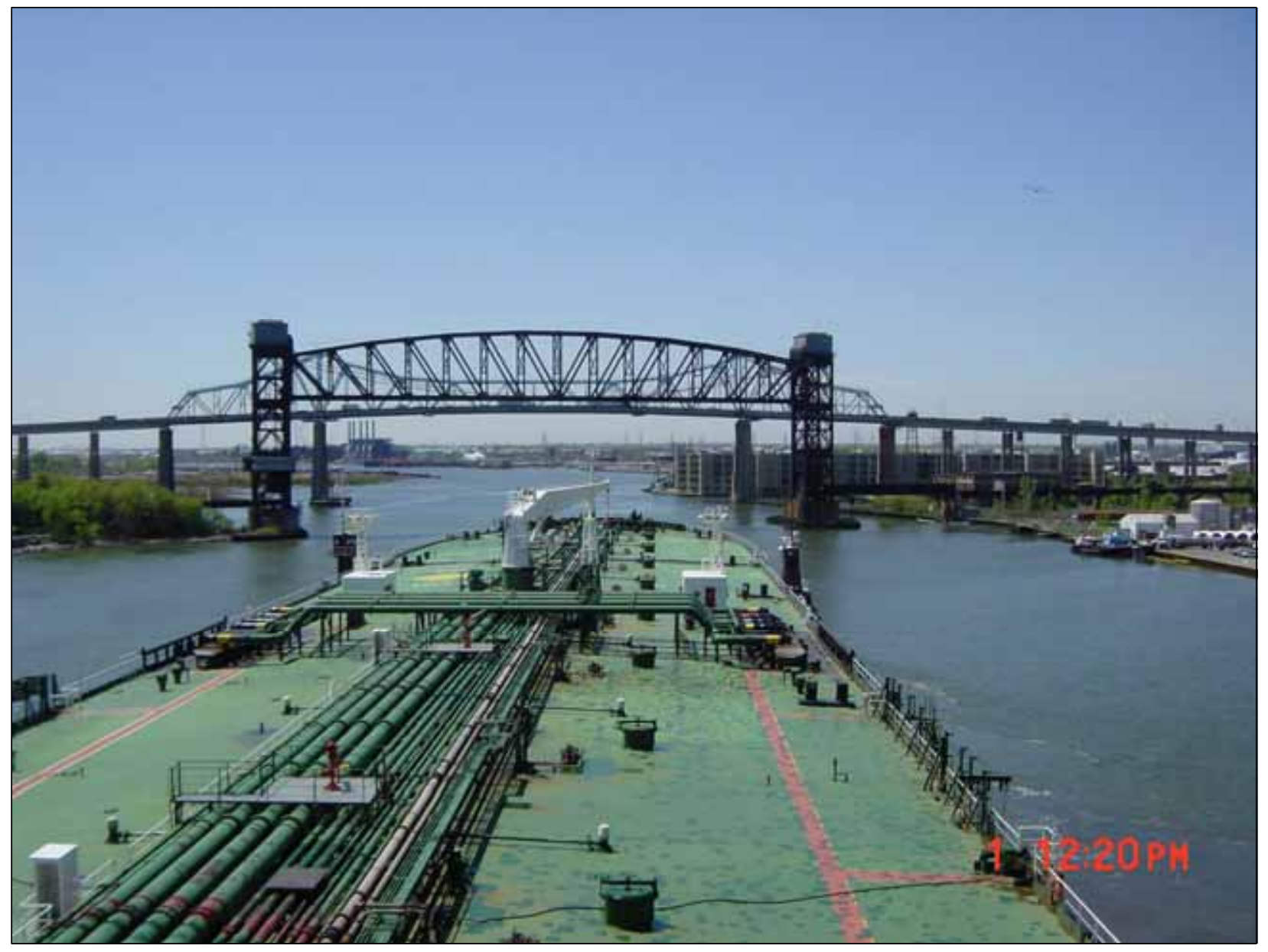

Figure 5. Tromso Trust approaching Bayway Bridge 


\section{Database Development}

Computer Science Cooperation (CSC), under contract to the U.S. Army Engineer Transportation School in Fort Eustis, VA, developed the visual scene for New York Harbor. CSC updated the visuals based upon data collected during the reconnaissance trip.

Currents for the proposed 50-ft channel were calculated at ERDC for the New York and New Jersey navigation study (1999). The mesh used for the previous study was modified to reflect the proposed channel deepening in Arthur Kill and new currents were obtained. Simulations were conducted for maximum ebb-and flood-tidal currents. The currents used to develop the simulation models are shown in Figures 6 and 7. Wind of 15 knots from the northwest was used for all simulations.

The SL Performance was used to represent container ship traffic in the existing conditions. The $S L$ Performance is $950 \mathrm{ft}$ long with a beam of $106 \mathrm{ft}$. The SL Performance was loaded to a draft of $33 \mathrm{ft}$ for the Arthur Kill simulations. The Susan Maersk was the design ship for container traffic in the proposed $50-\mathrm{ft}$ channel. The Susan Maersk is 1,139 ft long and has a beam of $141 \mathrm{ft}$. The Susan Maersk was fully loaded to a draft of $47.5 \mathrm{ft}$ for simulations. A 132K-ton tanker, $875 \mathrm{ft}$ long, 144-ft beam, drafting $37 \mathrm{ft}$ was used to simulate ships calling at Tosco refinery. Designers and Planners, Inc. developed the three ship models.

Available for the pilot's use were 4,000-hp tugs. An ERDC employee in the control room controlled the assist tugs. The pilot used a radio to request tug actions.

The new ERDC Ship/Tow Simulators have been operational since February 2002. The simulators are CSC Virtual Ship 2000 models. The simulators are realtime, i.e., ship movements on the simulator require the same amount of time as in real life. Environmental forces such as currents, wind, banks, ship-ship interactions all act upon the vessel during a transit. The pilot controls the simulated vessel's engine speed and rudder. The pilot also has radio contact with assist tugs. The Susan Maersk has bow and stern thrusters that are pilot-controlled. The two simulators can be coupled together for two-way traffic, but were run independently for the one-way Arthur Kill simulations. Figure 8 shows the ERDC simulator being operated during validation of the Arthur Kill study. 


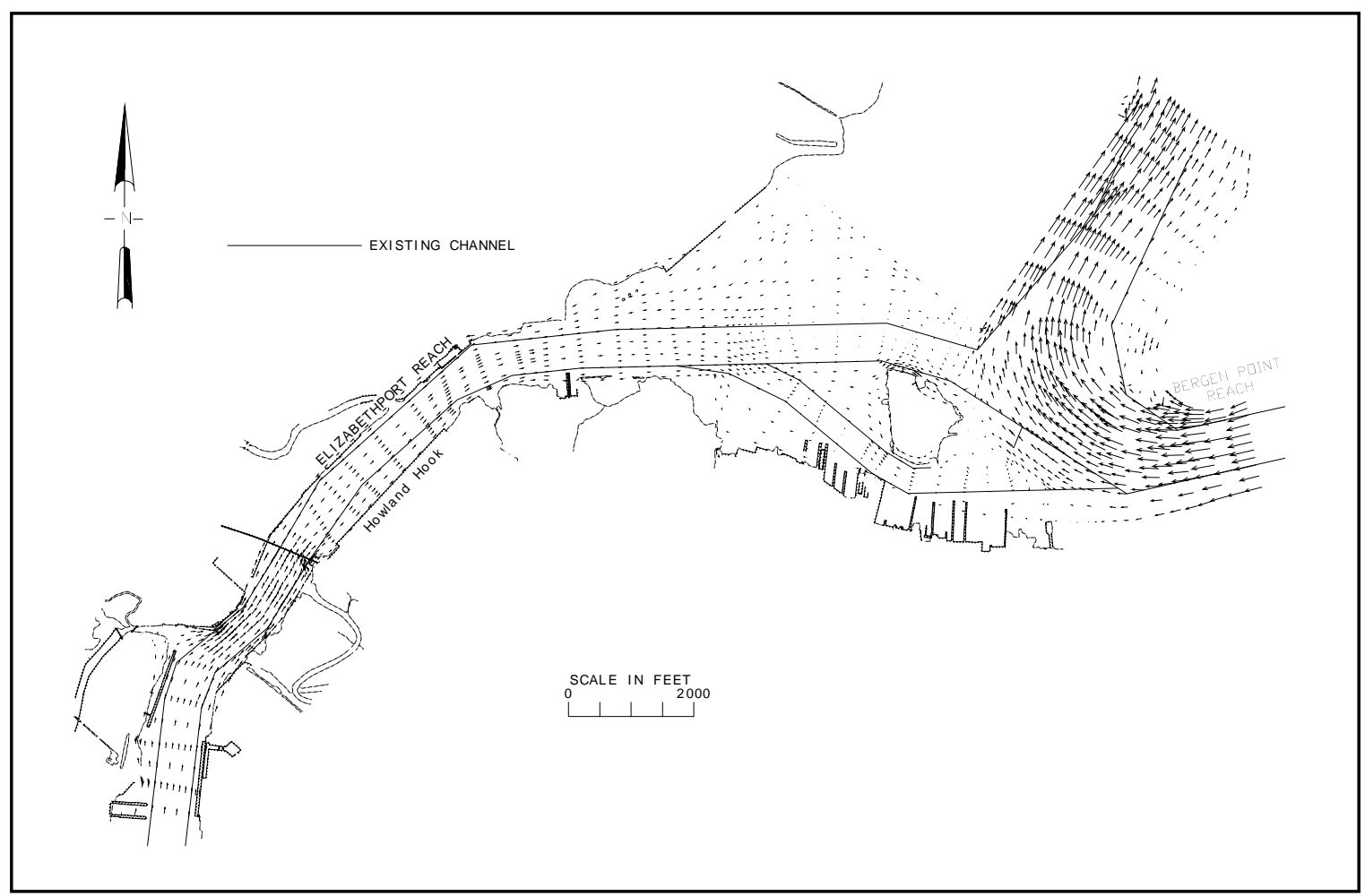

Figure 6. Ebb currents

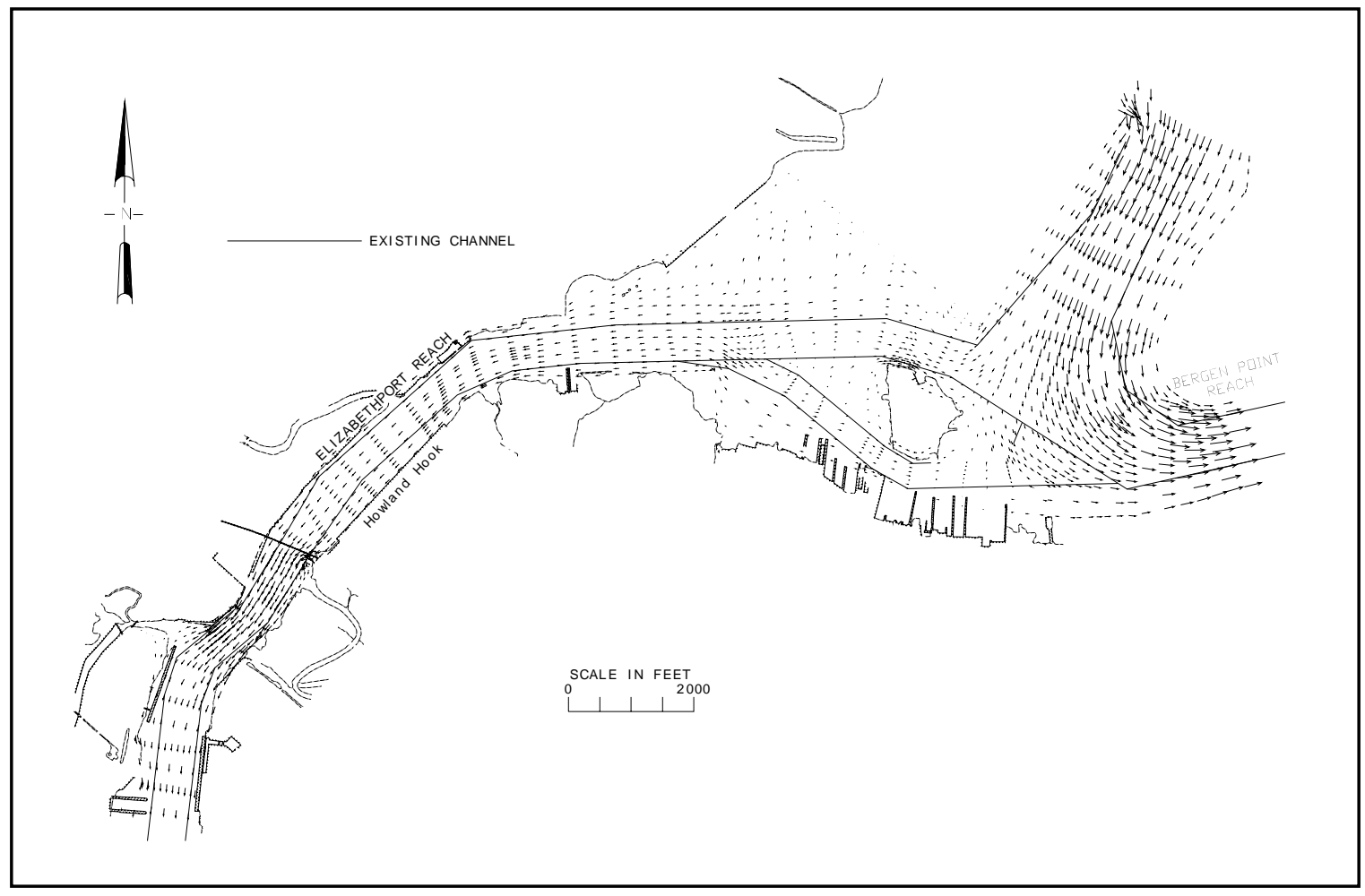

Figure 7. Flood currents 


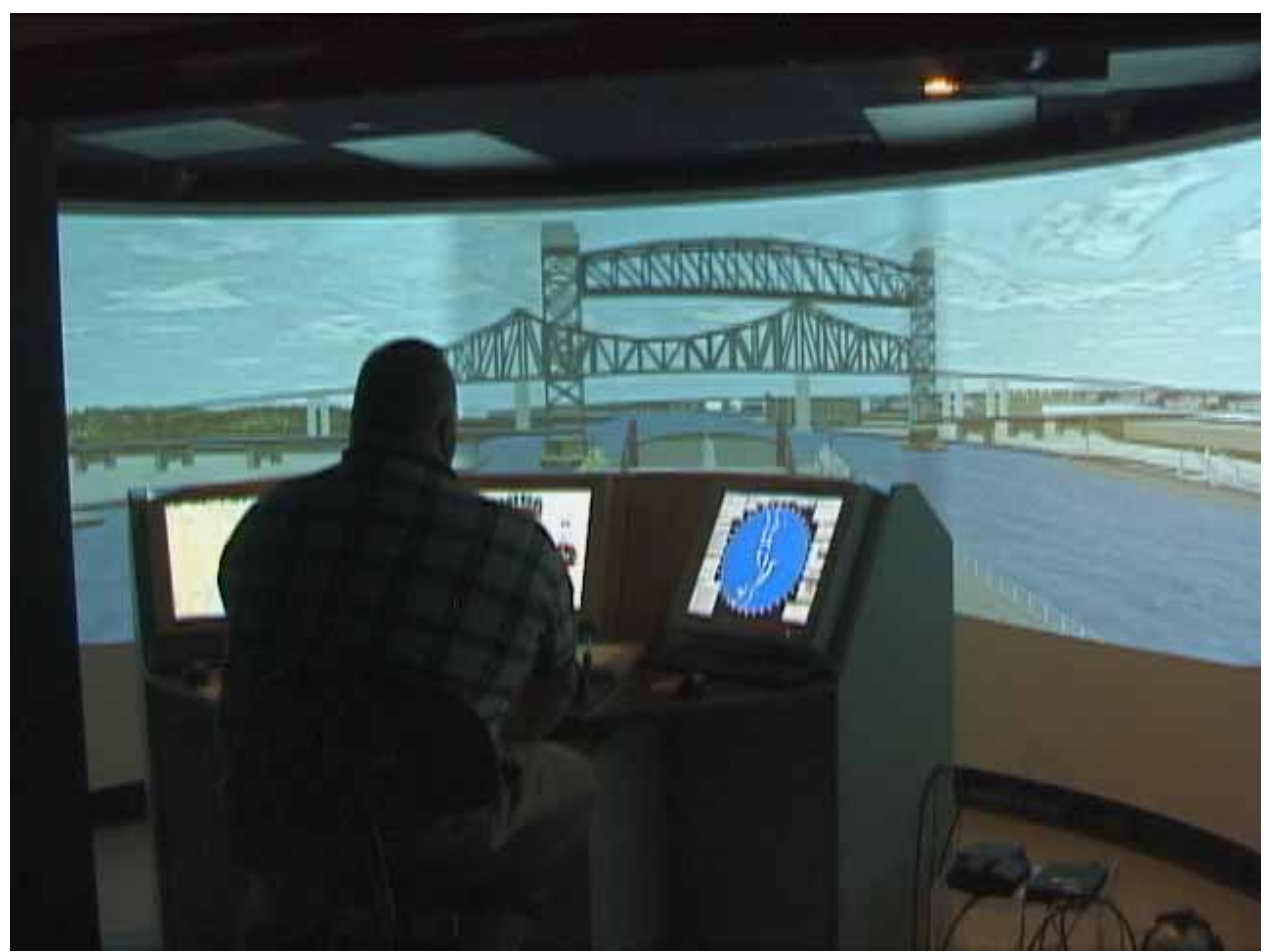

Figure 8. ERDC Ship/Tow Simulator view from tanker, approaching Bayonne Bridge

A plan of the ERDC simulator facility is shown in Figure 9. The facility consists of two bridge modules, a viewing area, a pilot debriefing room and an operator station. An illustration of a bridge module is shown in Figure 10.

The deepening of the Arthur Kill channels had no impact upon tankers transiting the reach to call at Tosco refinery.

Typically, pilots operate the simulator from the bow view as shown in Figure 8. However, for Arthur Kill, the outbound runs required backing the ship. For outbound runs, the pilot adjusted the simulator viewing angle to display both the bow and stern of the ship.

The pilots can rotate the simulator view as desired. For outbound runs, the pilots rotated the view 90 deg to the left. That way both stern and bow are visible on the right and left sides of the screen, respectively. Figure 11, shows orientation of the viewing angle and Figures 12 and 13 show the rotated bow and stern view, respectively. 


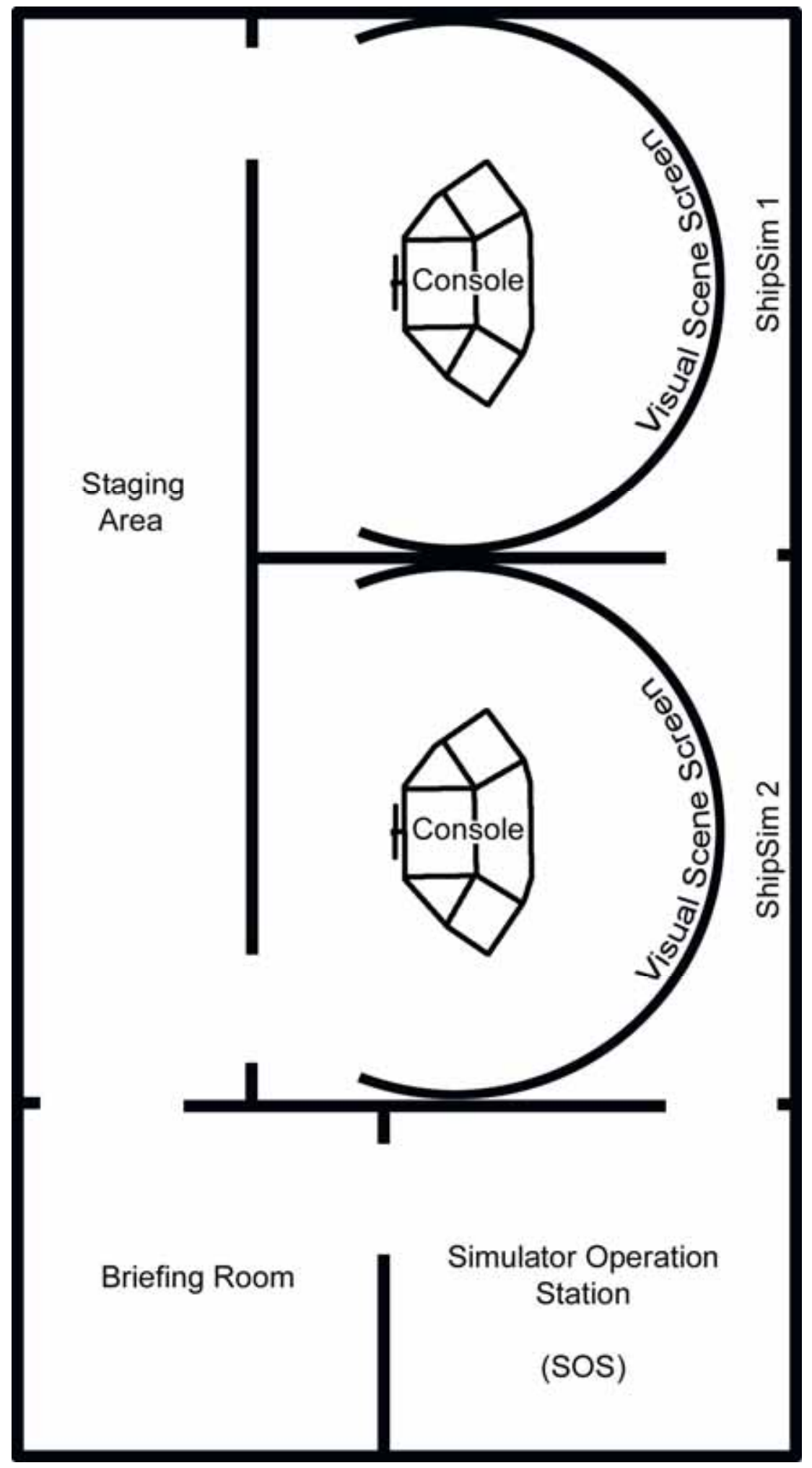

Figure 9. ERDC simulator layout 


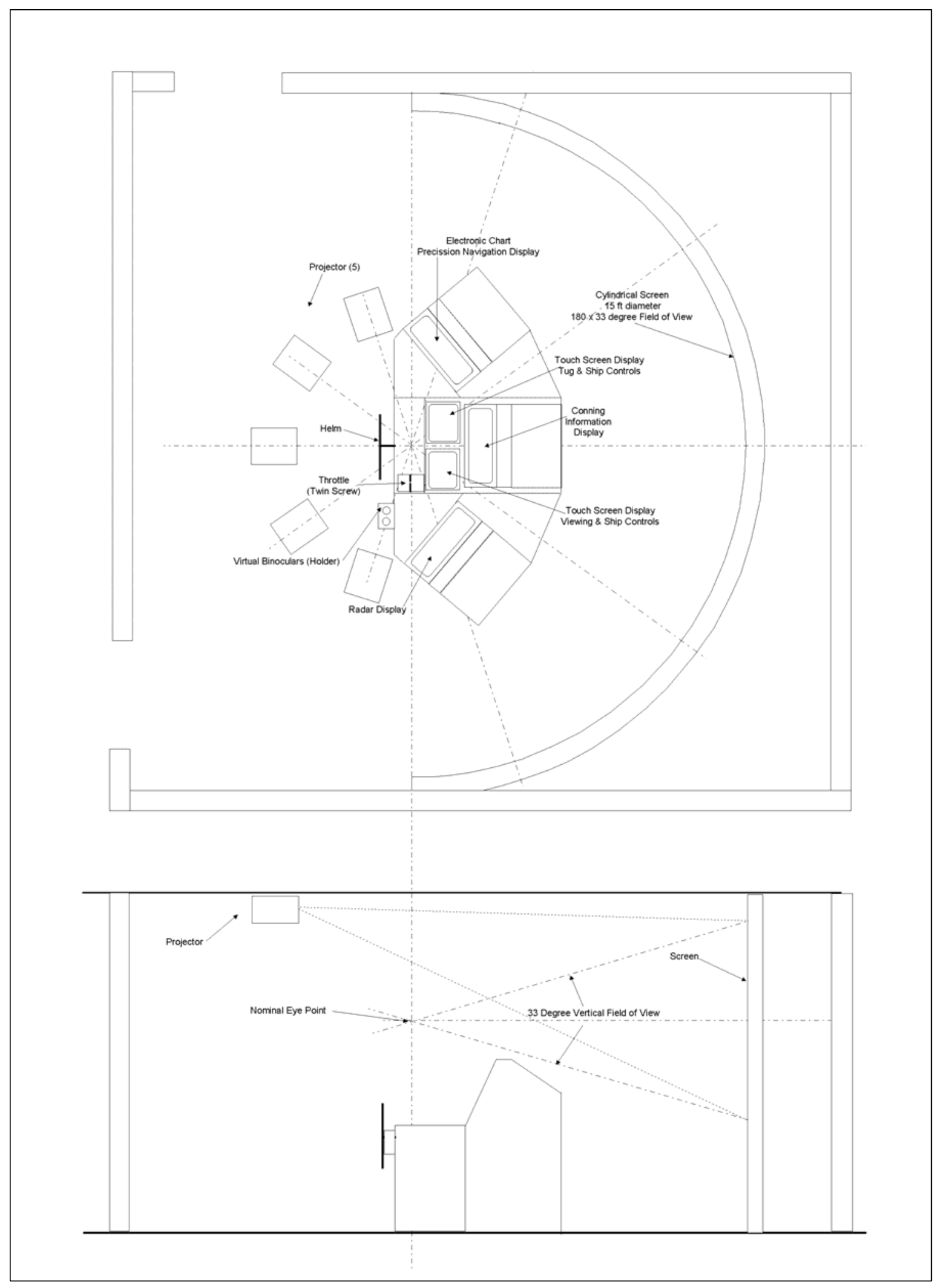

Figure 10. Arrangement of ERDC Ship/Tow Simulator bridge module 


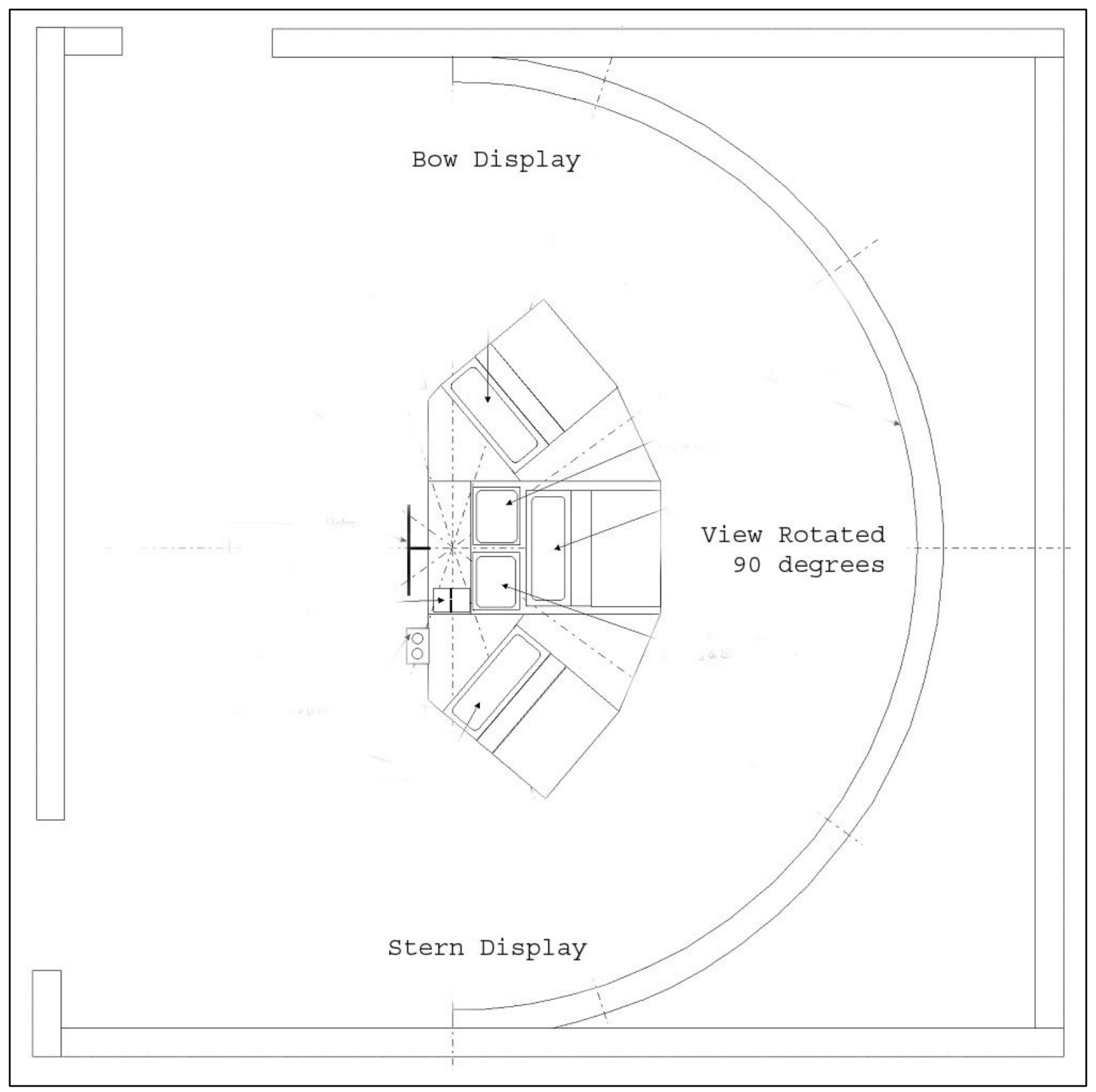

Figure 11. Viewing angle orientation used for backing in Port Jersey Channel 


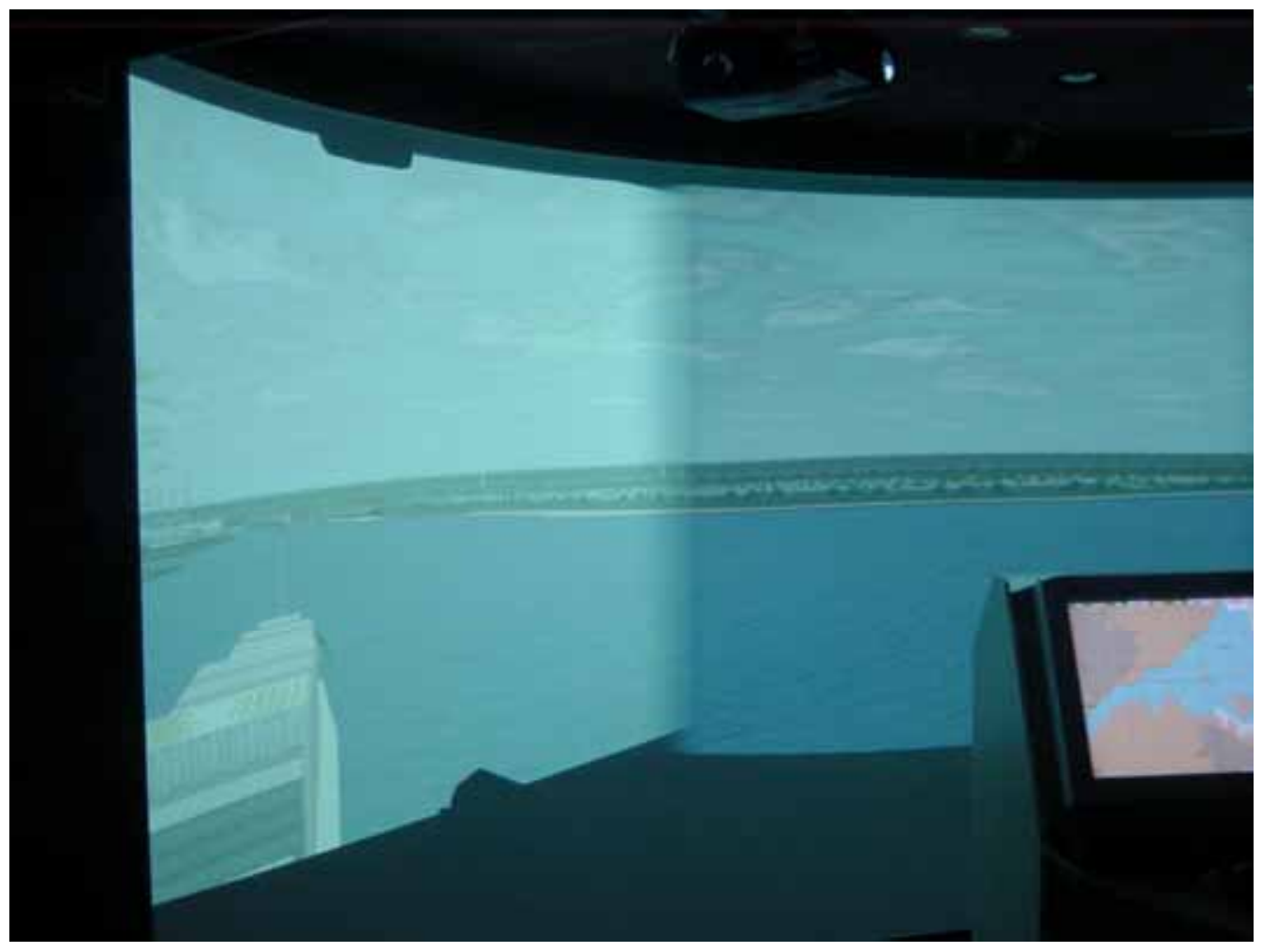

Figure 12. Rotated bow image on left side of screen

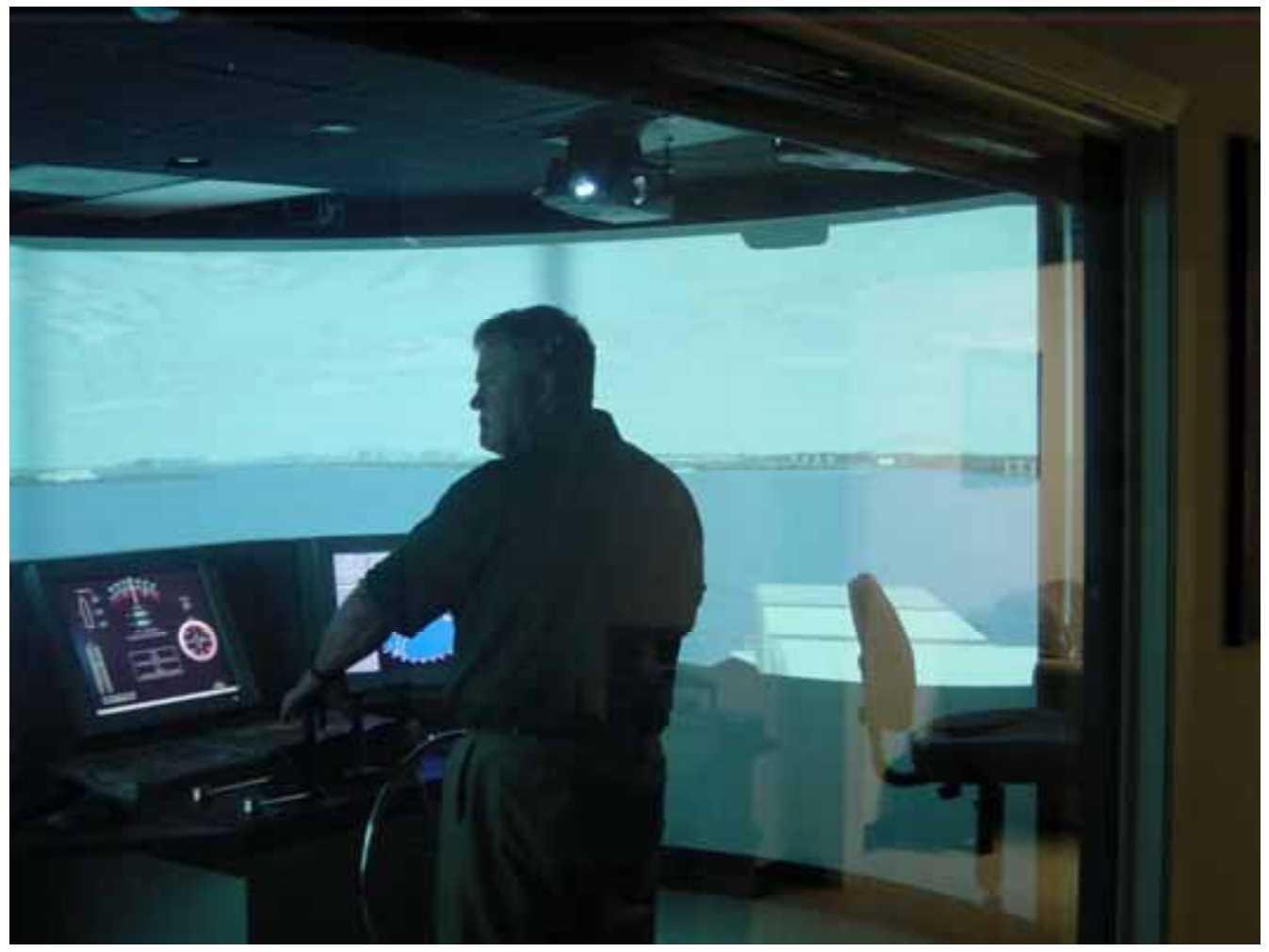

Figure 13. Rotated stern image on right side of screen 


\section{Study Results}

Navigation study results are presented in the form of track plots and pilot opinion. The track plots show the ship's position and heading at 1-min intervals. At the end of each simulation, the pilot was given a form to record his thoughts on the exercise. These forms are used during the analysis of the track plots. The pilots were also given a final questionnaire at the end of their simulation session. The completed questionnaires are included as an appendix to this report.

\section{Inbound Container Ship Scenarios}

Ebb tide. The track plots of the SL Performance transiting the existing channel in ebb tide are presented in Plate 1 . All ships kept to the north side of the channel while passing Shooter's Island. One ship crossed the northern channel limits of North of Shooter's Island Reach by approximately $20 \mathrm{ft}$. The ships remained in the northern half of the channel until making the turn onto Elizabethport Reach. Track plots of the Susan Maersk in the Plan 1 channel are shown in Plate 2. All ships remained in the northern half the channel and did not leave the authorized channel at any point during the exercises. The inbound, ebb tide runs for Plan 2 are shown in Plate 3. As in the existing and Plan 1 runs, the ships stayed on the northern side of the channel. None of the ships left the authorized channel.

Flood tide. The track plots of the SL Performance transiting the existing channel in flood tide are presented in Plate 4. The ships stayed on the northern side of the channel and none left the channel limits, although one ship did come within $5 \mathrm{ft}$ of the channel edge near the entrance to Newark Bay. Tracks of the Susan Maersk in Plans 1 and 2 channels are shown in Plates 5 and 6, respectively. The ships remained in the middle to northern half of the channels and did not cross the channel boundaries.

\section{Outbound Container Ship Scenarios}

The outbound container ship simulations were the most difficult of those attempted during this study. Because there is no turning area, the ships must back east from Howland Hook and turn in the mouth of Newark Bay. The backing maneuver is more than 2 miles long and is very tedious. Tug assistance is required during most of the transit. 
Outbound, ebb tide. Track plots of the SL Performance backing out of the existing Arthur Kill channel during ebb tide are shown in Plate 7. One ship left the west end of North of Shooter's Island Reach by nearly $100 \mathrm{ft}$. The ship went out of the north side of the channel. Another run left the North of Shooter's Island Reach by approximately $60 \mathrm{ft}$. This occurred on the north side of the channel, approximately midway through the channel. All ships turned successfully in Newark Bay.

Track plots of the Susan Maersk backing out of the Plan 1 channel are shown in Plate 8. One ship left the west end of North of Shooter's Island Reach, in nearly the exact location as that in the existing channel. This ship left the channel by nearly $40 \mathrm{ft}$. Another ship crossed the authorized channel by about $5 \mathrm{ft}$ midway through North of Shooter's Island Reach. All ships turned successfully in Newark Bay.

Track plots of the Susan Maersk backing out of the Plan 2 channel are shown in Plate 9. One ship left the west end of North of Shooter's Island Reach, by about $50 \mathrm{ft}$. It should be noted that Plans 1 and 2 are identical in this area. That was the only incident of a ship leaving the channel in the Plan 2 outbound runs.

Outbound, flood tide. Track plots of the SL Performance backing out of the existing Arthur Kill channel during flood tide are shown in Plate 10. One ship left the west end of North of Shooter's Island Reach by approximately $75 \mathrm{ft}$. The ship went out of the north side of the channel. Another run left the North of Shooter's Island Reach by nearly $200 \mathrm{ft}$. This occurred on the north side of the channel, approximately midway through the channel. This occurred as he was beginning the southern turn at the eastern end of North of Shooter's Island Reach. The ships turned successfully in Newark Bay.

Track plots of the Susan Maersk backing out of the Plan 1 channel during flood tide are shown in Plate 11. Two ships left the west end of North of Shooter's Island Reach. Both ships left the channel by approximately $100 \mathrm{ft}$. Another ship crossed the authorized channel about by about $60 \mathrm{ft}$ midway through North of Shooter's Island Reach. All ships turned successfully in Newark Bay.

Track plots of the Susan Maersk backing out of the Plan 2 channel are shown in Plate 12. Two ships came close to the channel's edge near the west end of North of Shooter's Island Reach, but neither left the channel. As previously observed, Plans 1 and 2 are identical in this area. Both ships used the straightened end of North of Shooter's Island Reach as provided by Plan 2.

\section{Inbound Tanker Scenarios}

The tankers call at Tosco drafting $37 \mathrm{ft}$, at slack high water. The deepening project ends at the Bayway Bridge. Therefore, the tankers' draft will not increase as a result of the deepening project. After discharging their cargo, the empty tankers do not turn and sail out the same channels they sailed in on. Instead, they leave the harbor by heading south from Tosco. The simulations for existing and Plan 1 channels were conducted with the tanker draft of $37 \mathrm{ft}$. 
Plots of the tanker runs are shown in Plates 13 and 14, for the existing and Plan 1 channels, respectively. The existing channel runs (Plate 13) shows on ship left the eastern end of North of Shooter's Island Reach by approximately $60 \mathrm{ft}$. One ship left the south side of the Elizabethport Reach near Howland Hook. The ships transiting in the Plan 1 channel stayed on the northern side of North of Shooter's Island Reach and transited the project without incident. 


\section{Conclusions and Recommendations}

The Susan Maersk, at a draft of $47.5 \mathrm{ft}$, is significantly larger than container ships presently using Arthur Kill. Simulation results indicate that either Plan 1 or Plan 2 of the proposed deepened channel will be adequate for inbound runs. However, backing these large ships out of Arthur Kill is a slow and tedious process. The track plots show that the Plan 1 simulations were fairly successful when compared to the existing runs. However, it was obvious during observation of these simulation exercises that the pilots were having difficulties with the dogleg to the south on the eastern end of North of Shooter's Island Reach. Therefore, we recommend Plan 2 which straightened the eastern end of North of Shooter's Island Reach.

The deepening of the Arthur Kill channels had no impact upon tankers transiting the reach to call at Tosco refinery. 


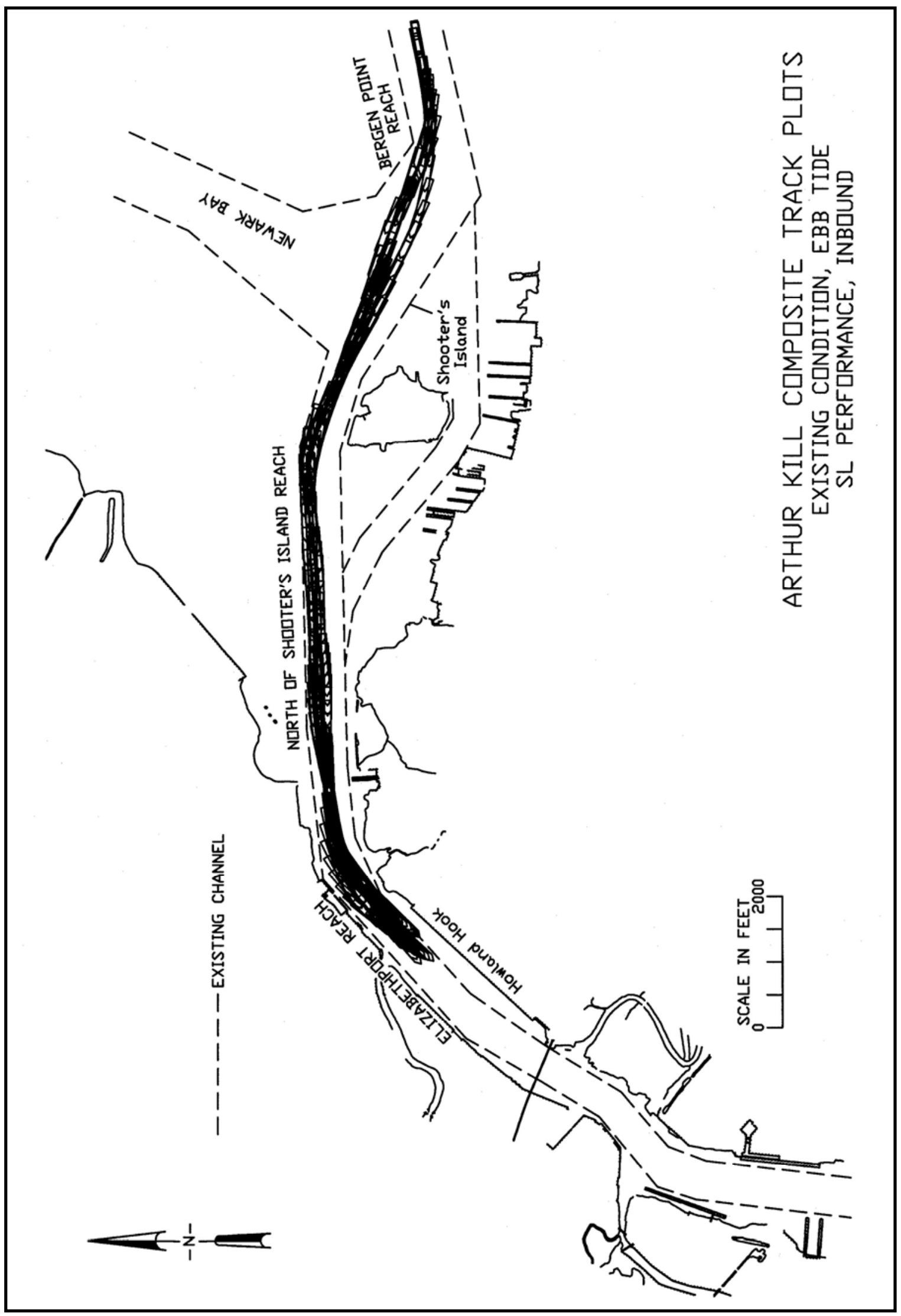

Plate 1 


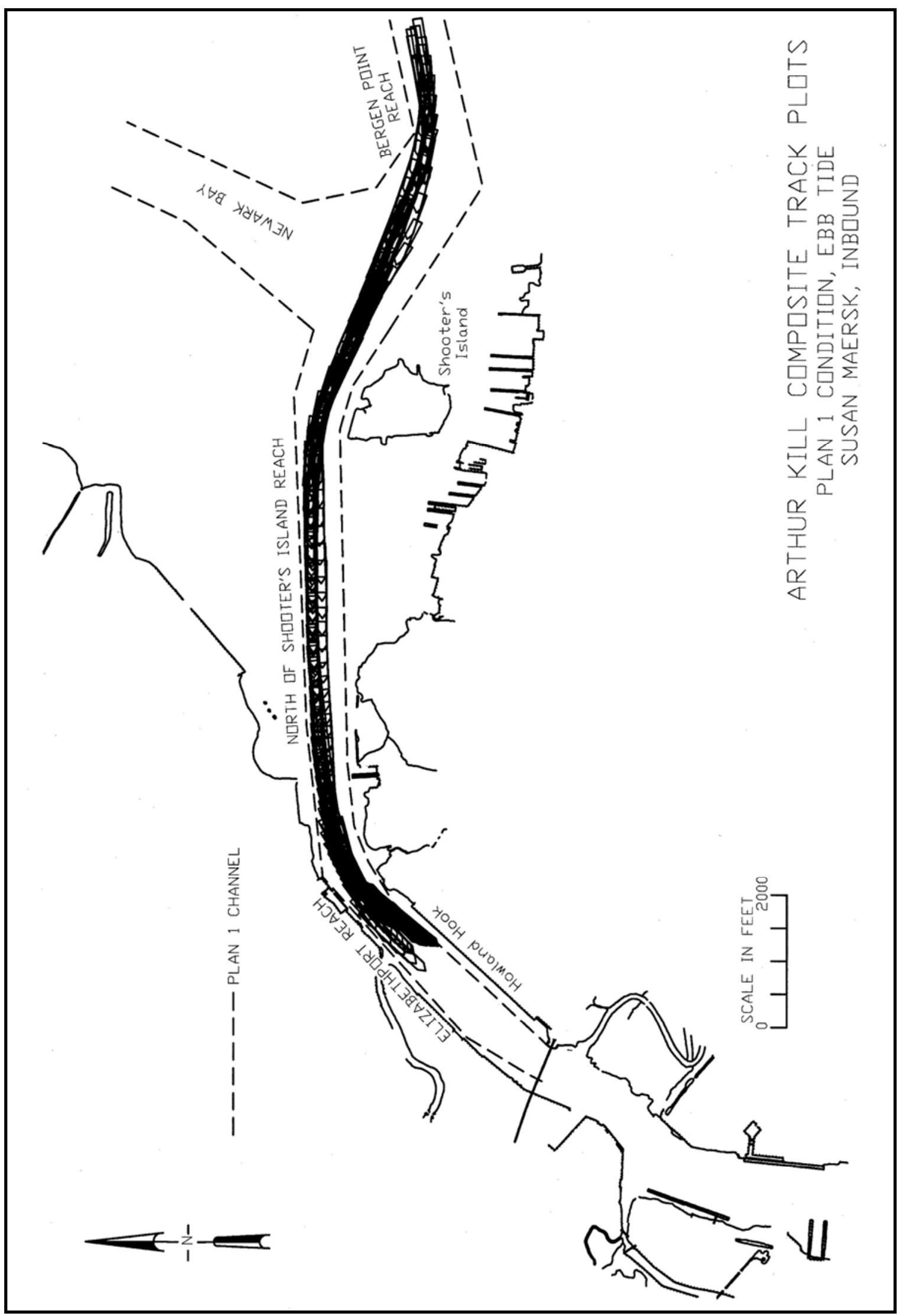

Plate 2 


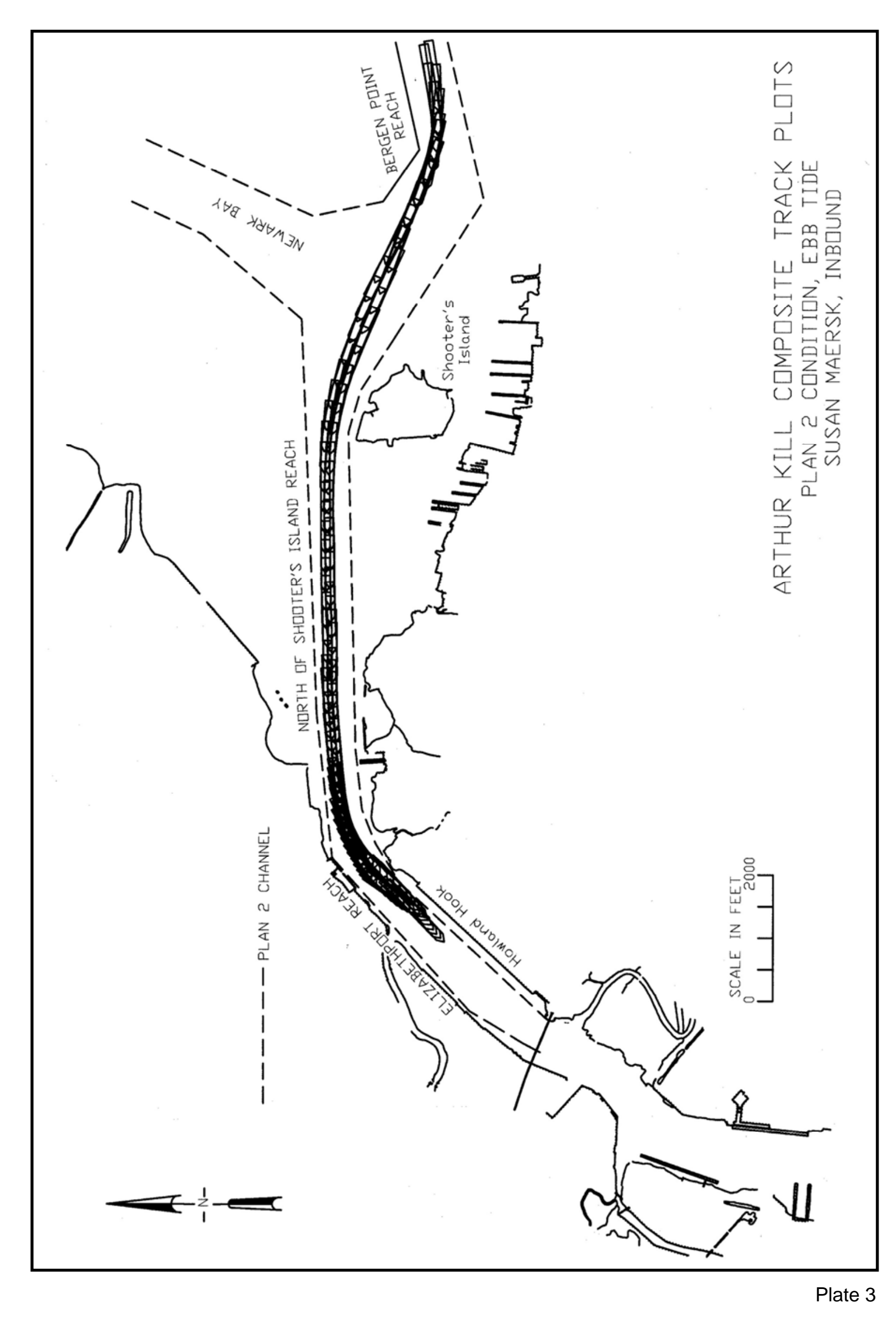




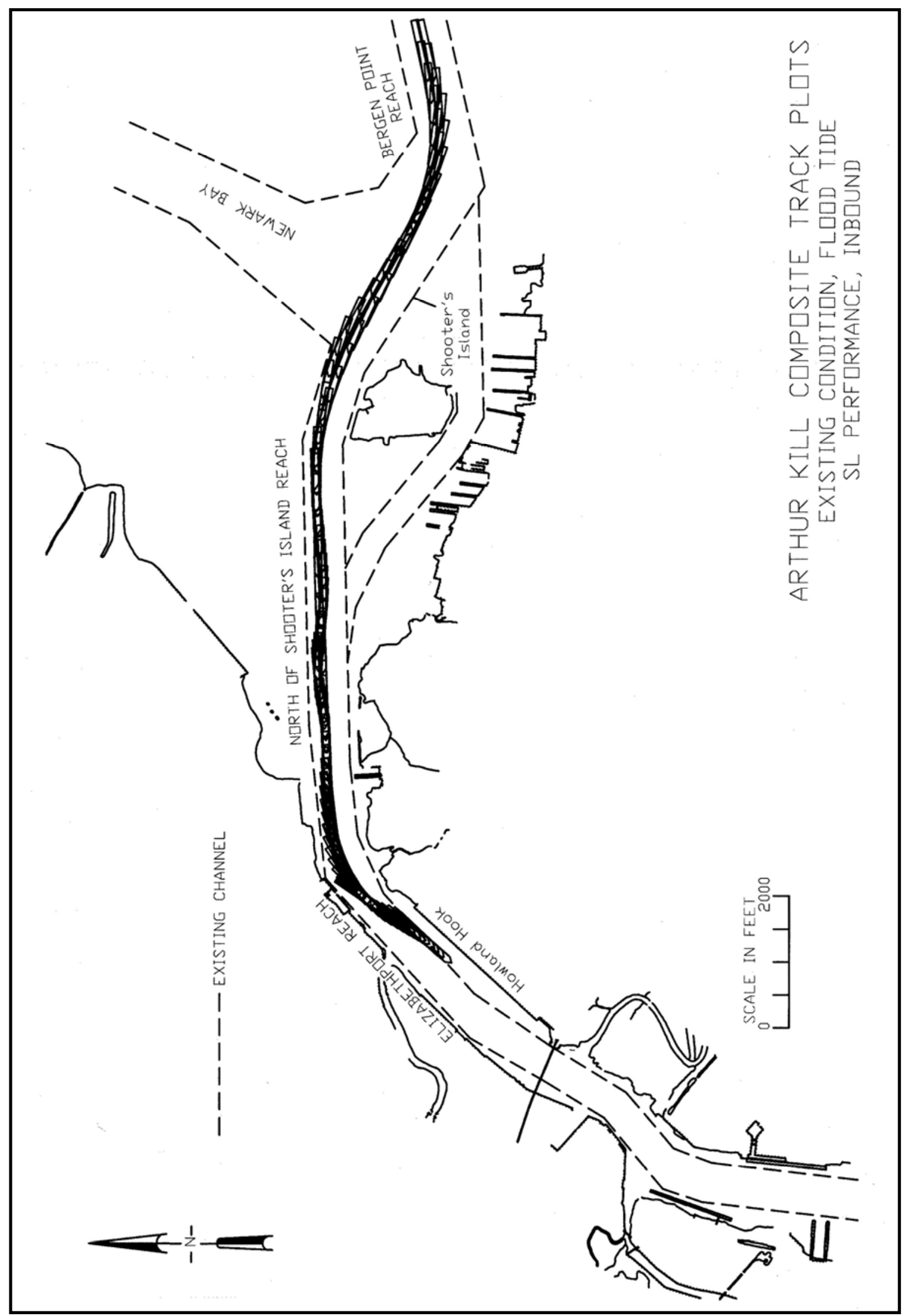

Plate 4 


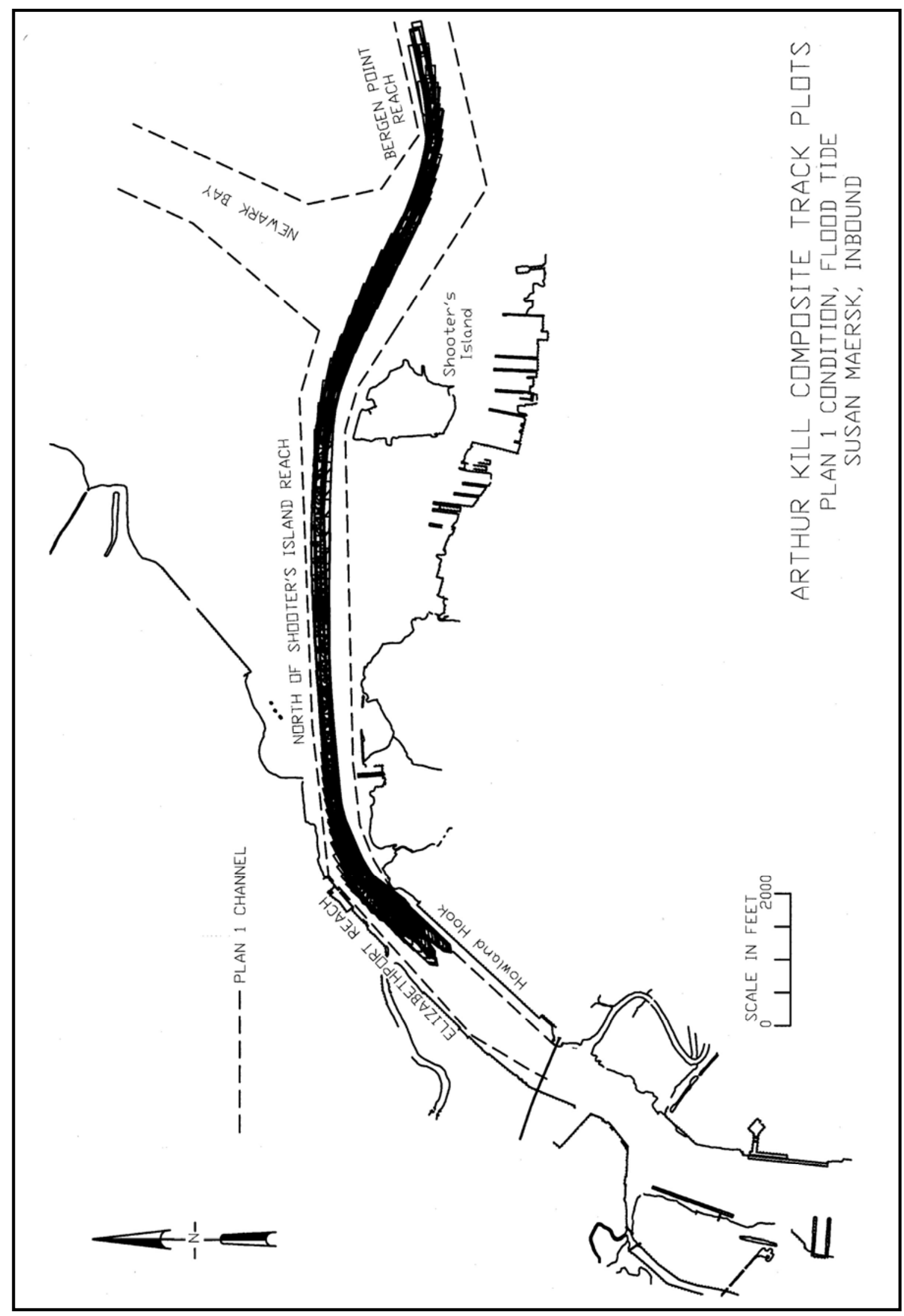

Plate 5 


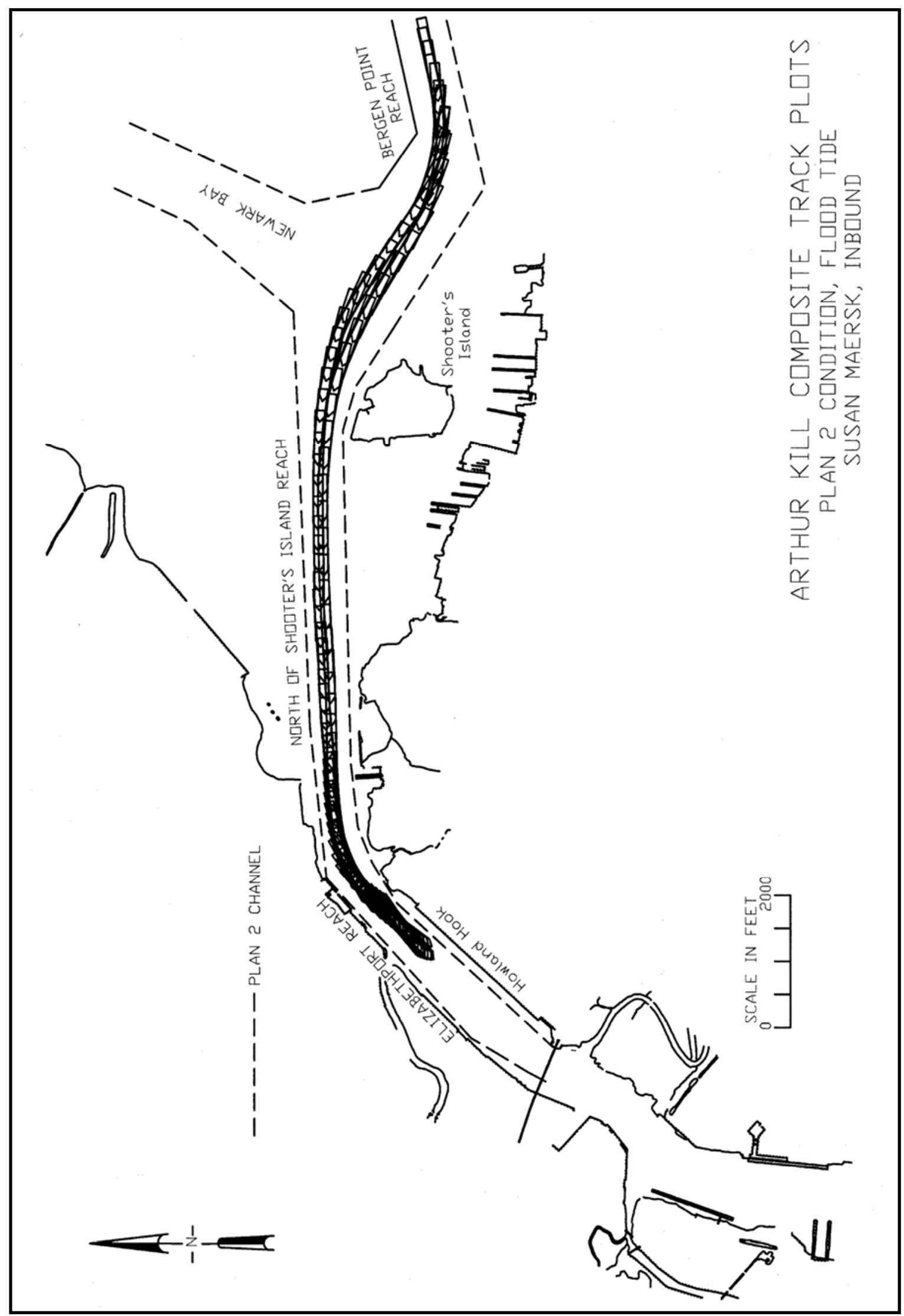

Plate 6 


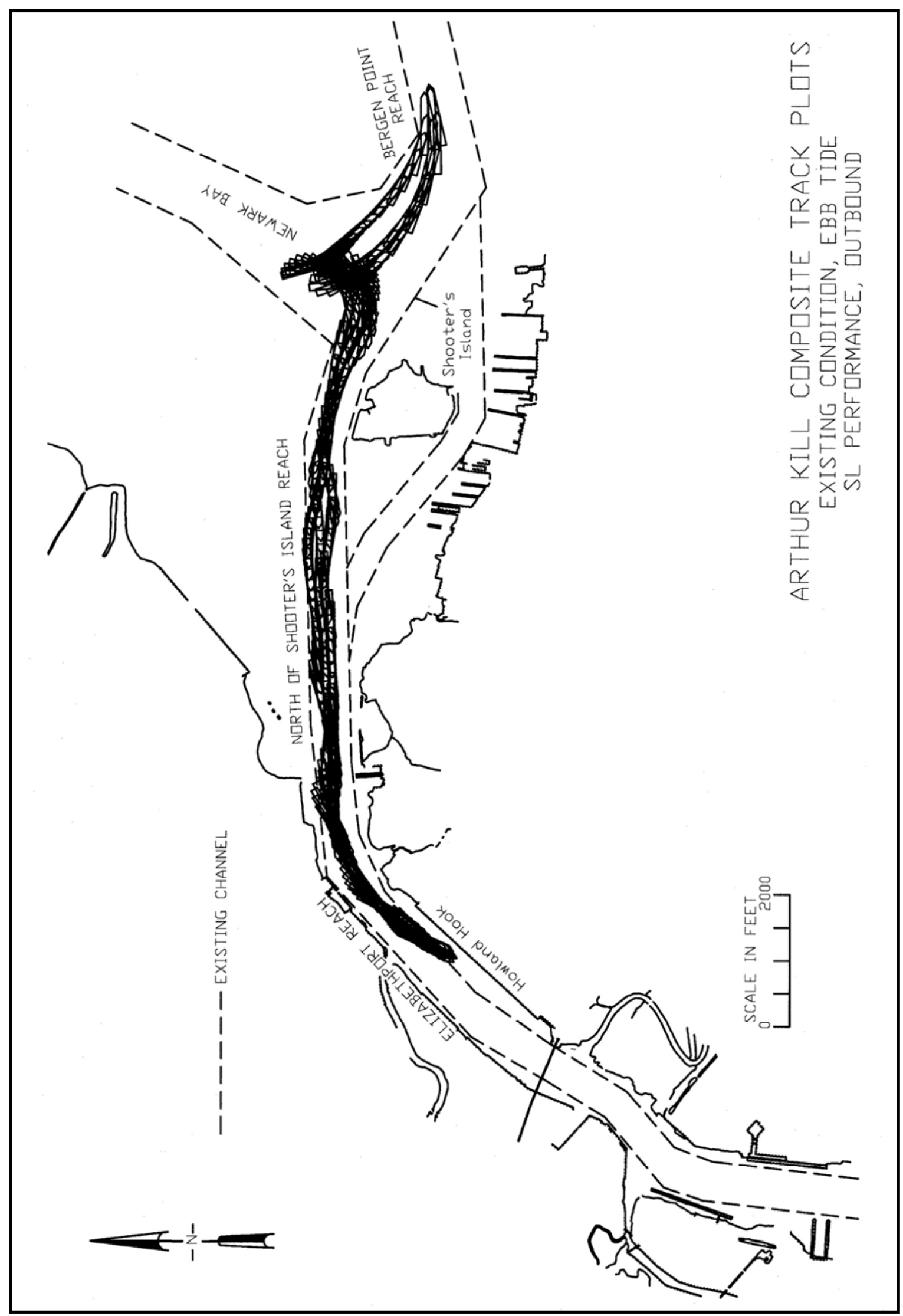

Plate 7 


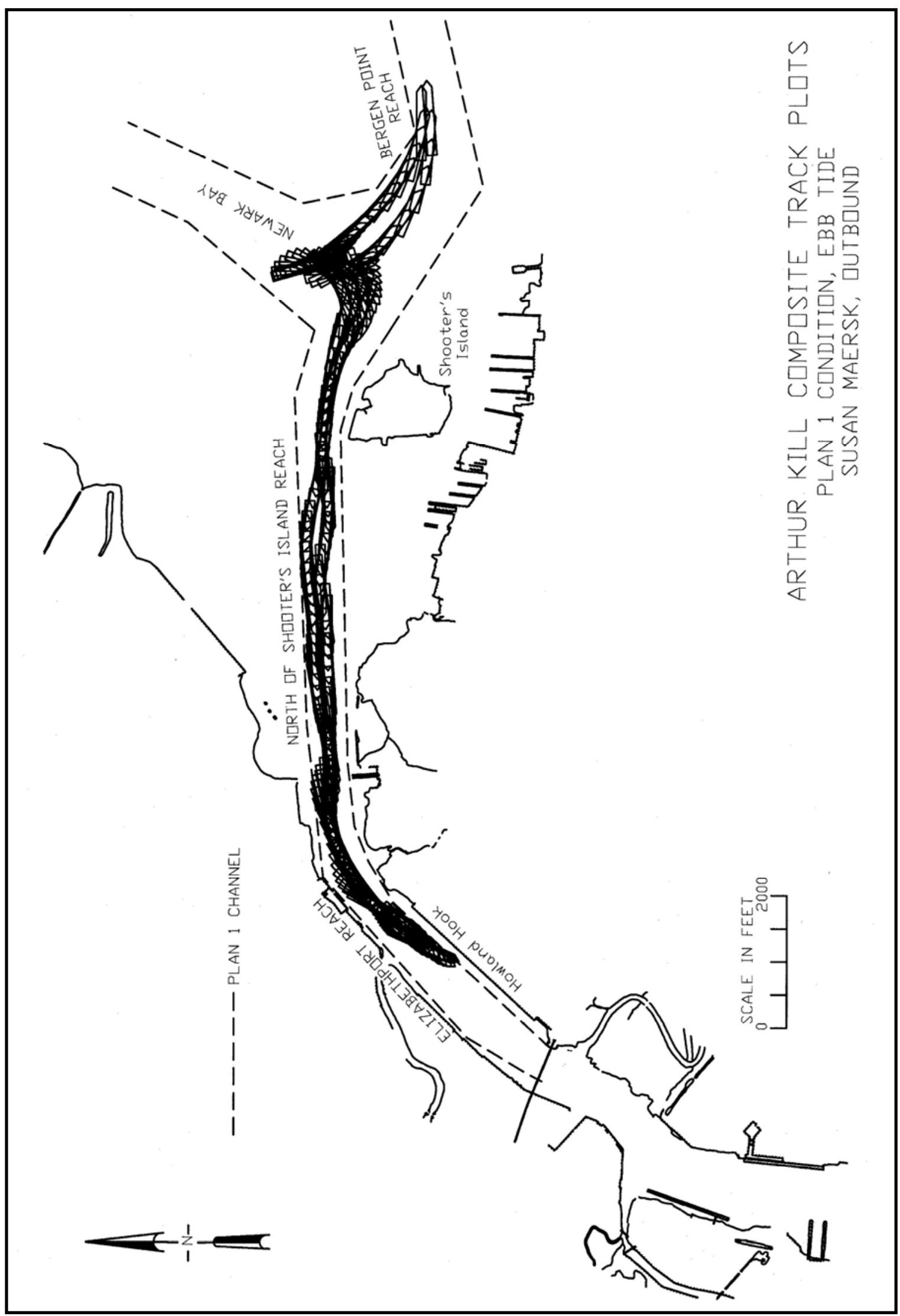

Plate 8 


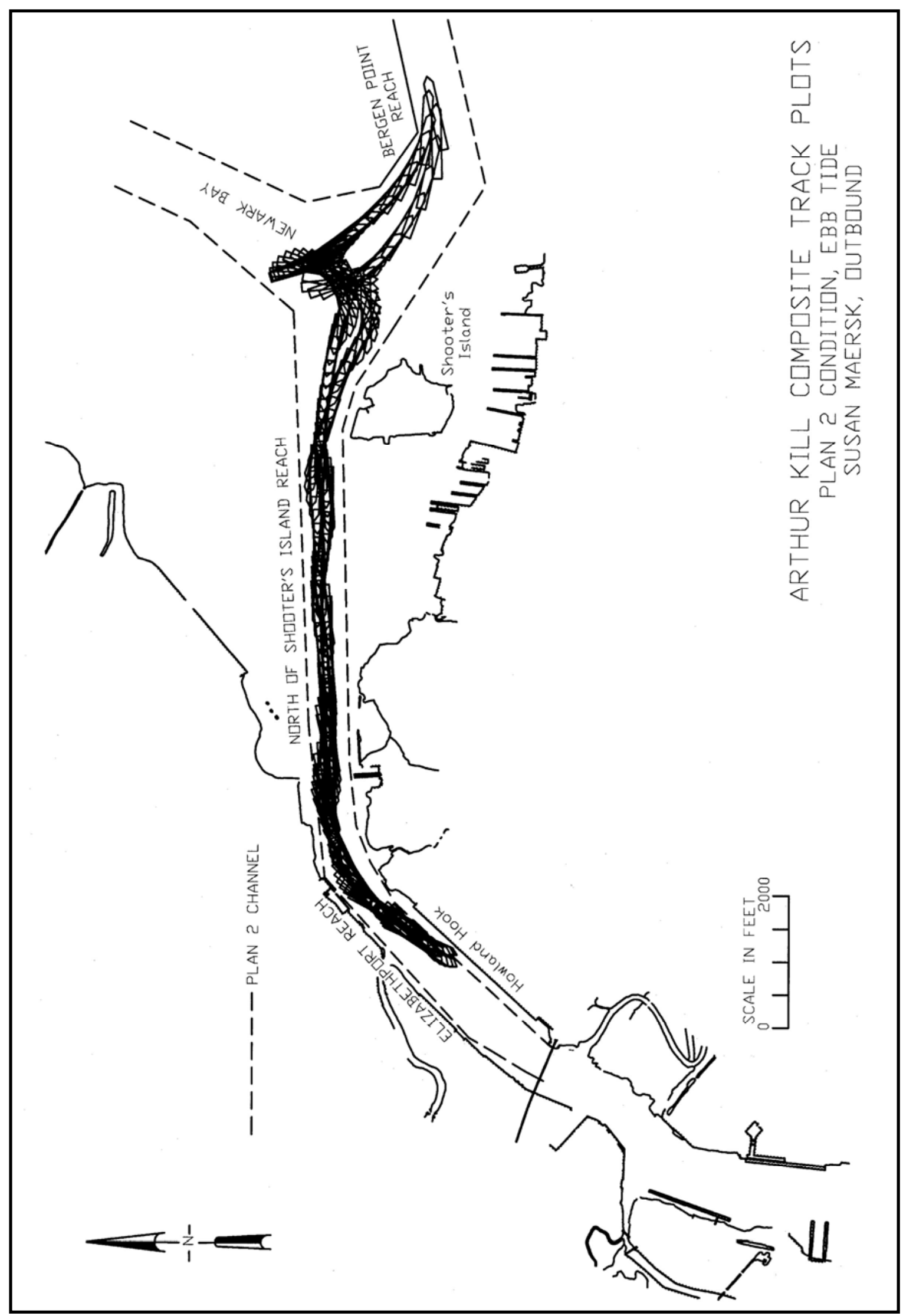

Plate 9 


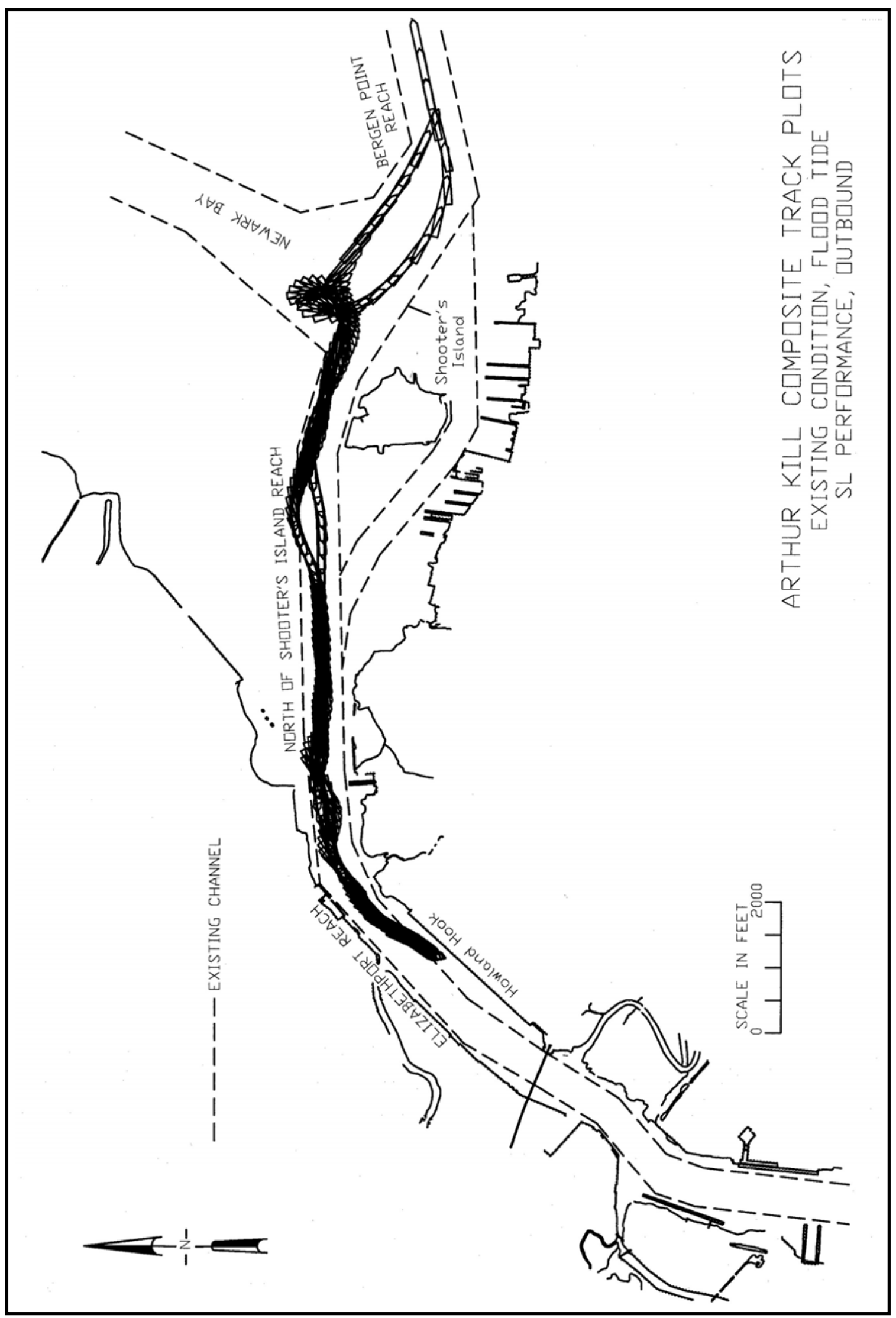

Plate 10 


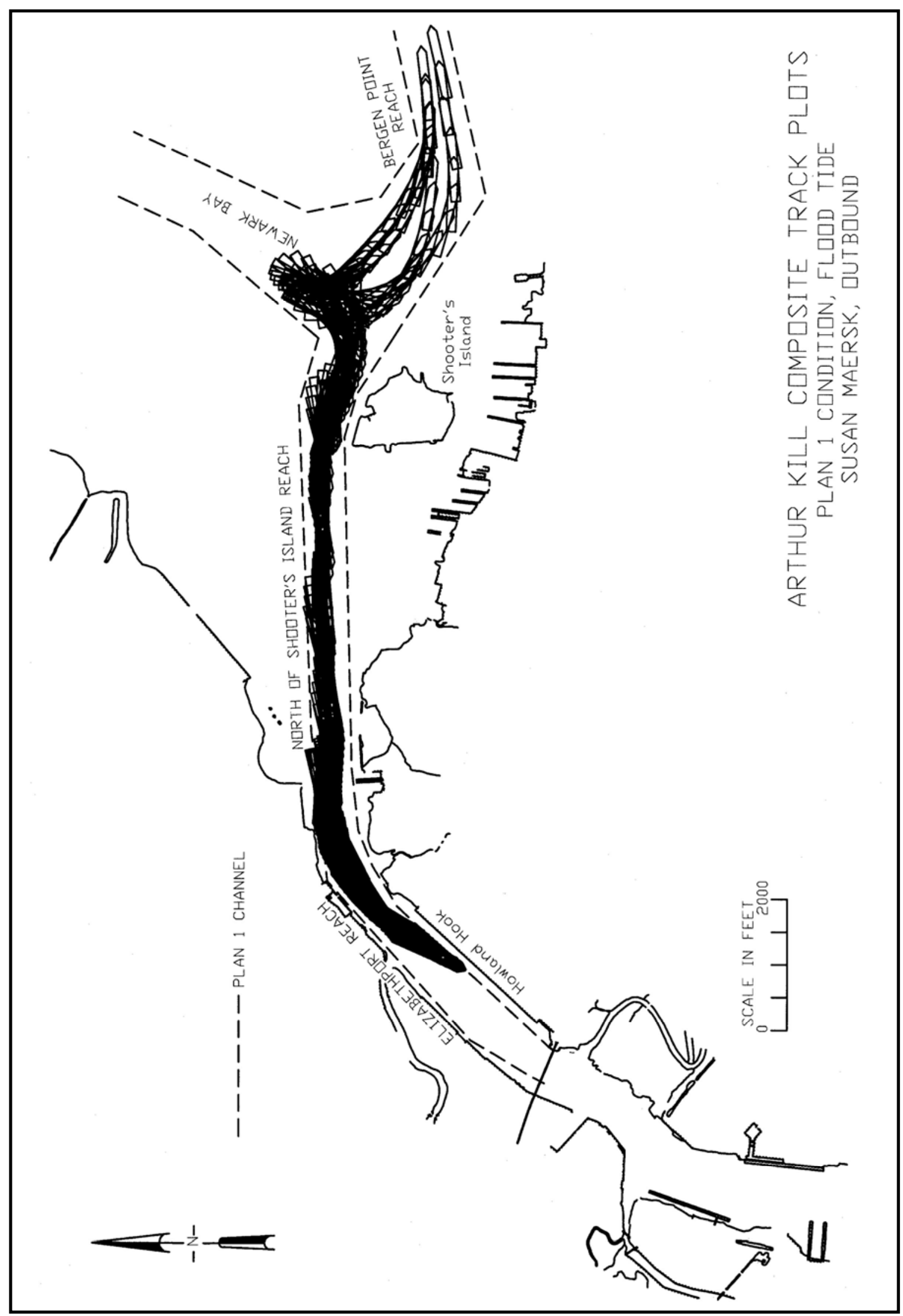

Plate 11 


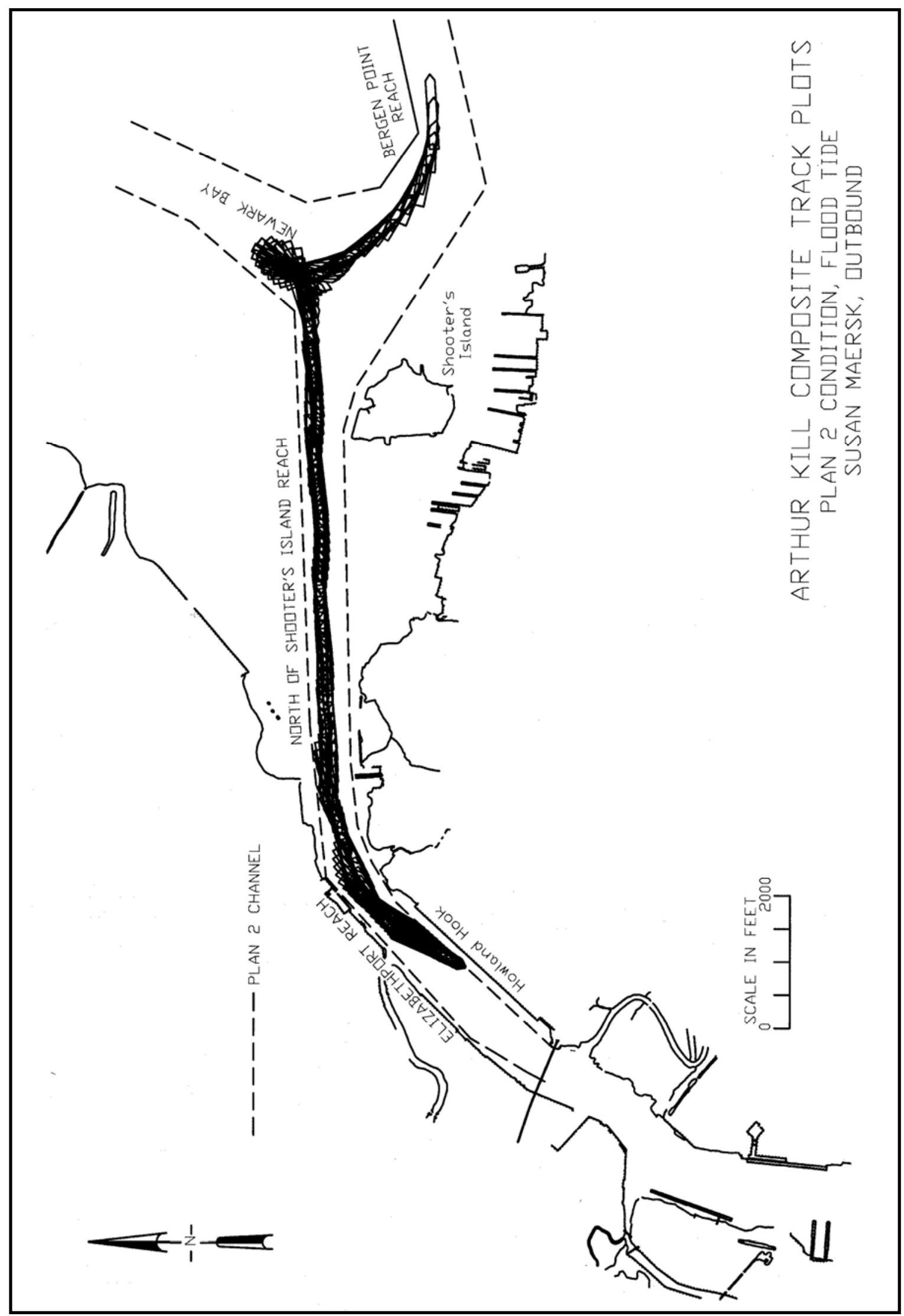

Plate 12 


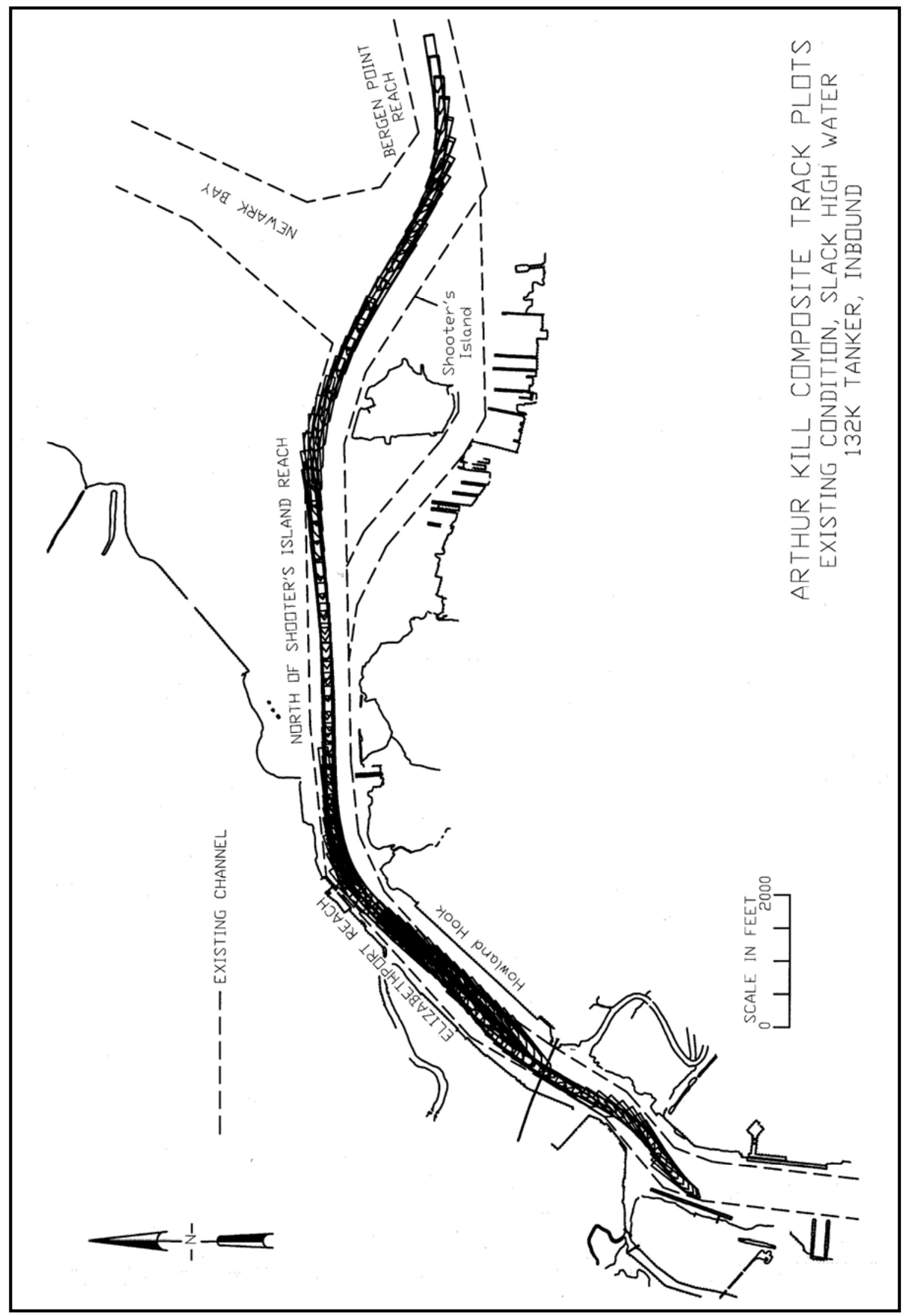

Plate 13 


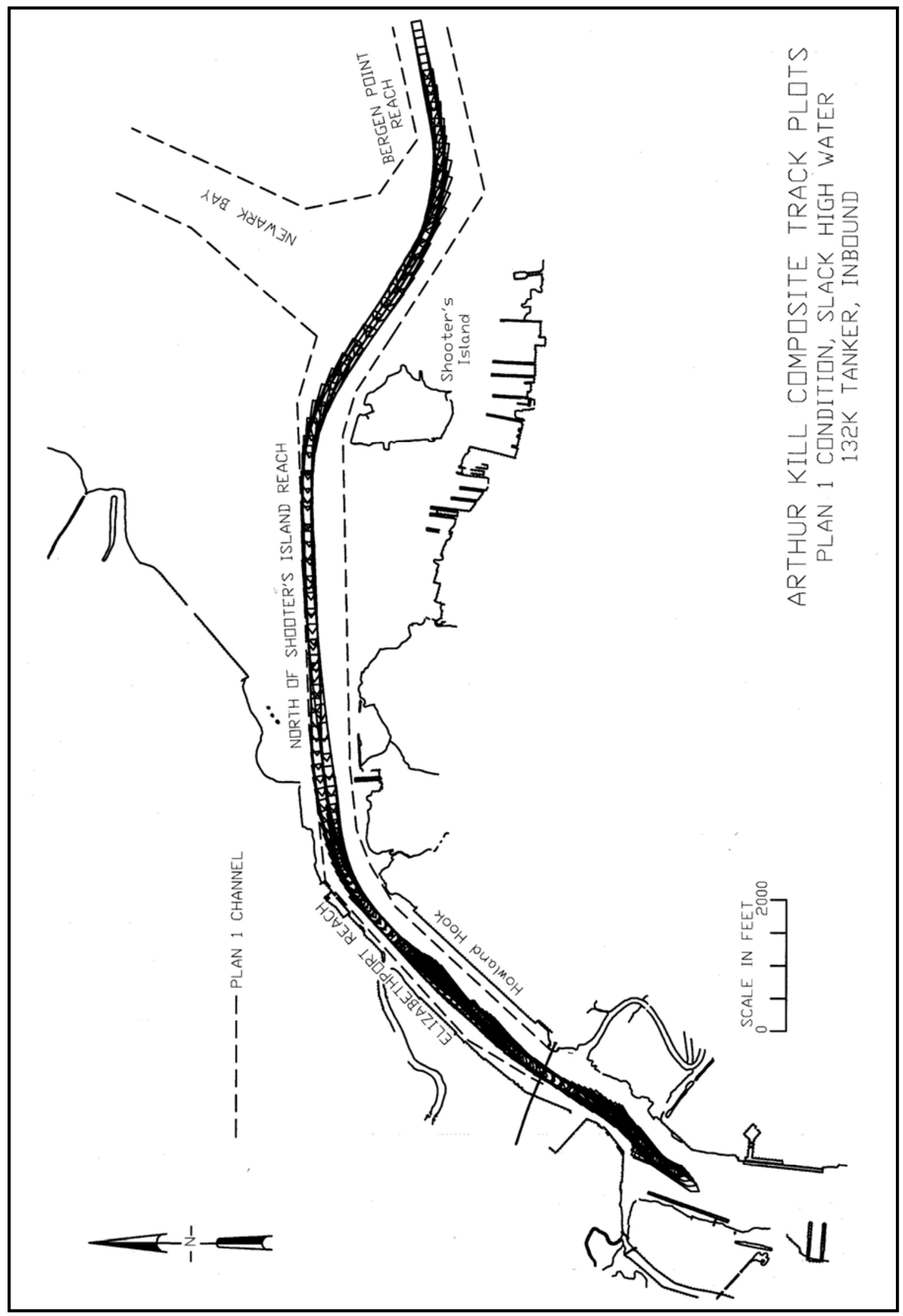

Plate 14 


\section{Appendix A Final Questionnaire}

Please answer the following questions based upon your simulation runs. Please elaborate if different responses are necessary for different tide/wind situations. Please comment on possible requirements for navigation, such as the number of tugs required for a given maneuver.

1. Please include any comments you may have on the proposed deepening of Arthur Kill.

a. When backing down from Howland Hook with the Susan Maersk class ships you will need 3 tugs.

I suggest they put a new dike in after taking out the old dike.

b. As far as the Susan Maresk handling to the 50' channel the ship at 46' draft was good and felt real.

c. If the Arthur Kill is deepened for very large vessels and not widened it would be likely restricted to one-way traffic. Air draft may be a problem for these large vessels. The knuckle just east of Howland Hook I think is a problem. It should be removed or at least diminished. Backing these large vessels down to Newark Bay to turn them is always risky.

d. The proposed deepening of Arthur Kill will be of great benefit to both Tosco Bayway and Howland Hook Container Terminal the straightening of the first dog-leg in the channel off of Shooters Island will make it a safer transit to and from these terminals. We have proved that it is safe to bring ships the size of the Susan Maersk into and out of Howland Hook. I bet it will be challenging to do so. Because pilots in N.Y. have not had this size or draft ship in real life, it will require a lot of learning on our part. I believe the economic benefits of the deepening will help the Port of NY and NJ become more competitive.

2. Do you feel environmental conditions (current, wind, banks, etc.) were accurately simulated and represent navigation conditions under which Arthur Kill will operate?

a. I think the wind and tide conditions were right on the money excellent simulation. 
b. The current and wind were good. I did not feel the bank effects at anytime.

c. The currents seemed to be ok. I didn't notice any wind effect. Also I didn't feel any bank effects.

d. I felt the above conditions were accurately simulated for the Arthur Kill exercise.

3. Please comment of the behavior of the simulation model of the Susan Maersk. Include the response of the ship to tugs.

a. I believe the tugs should have been able to push the ship around better.

b. The response to the tugs. You need three tugs and the HP did not seem to be enough. When the ship started to swing coming astern the tugs couldn't stop the ship without the use of the ship engine.

c. Going ahead she acts like a vessel of her size and weight. But going astern she was directionally unstable. Using three tugs appropriately this could be controlled with a great deal of work.

d. The model of the Susan Maersk seemed to respond to the tugs accurately. I was a little disappointed with the response to the bow of the ship when pushed on by the 4,000/hp tug. I think the bow will move faster giving the pilot more control over backout maneuvers. I think it will be easer to straighten the ship up than it was on the simulator.

4. Do you have any additional comments concerning the Port Jersey simulation model or the ERDC Ship /Tow Simulator?

a. No response.

b. No response.

c. The visual is very good. The best I've seen. The electronic plotter (ECDIS) seems not to follow the vessel with accuracy. At times it showed the vessel aground when the vessel was in the middle of the channel.

d. No response. 


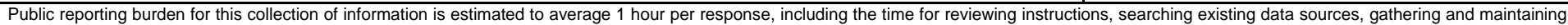

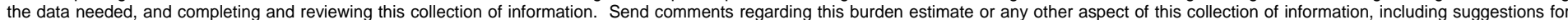

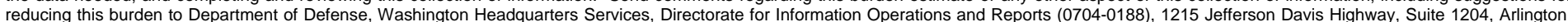

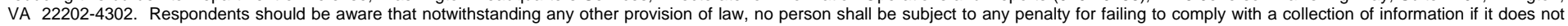
display a currently valid OMB control number. PLEASE DO NOT RETURN YOUR FORM TO THE ABOVE ADDRESS.
1. REPORT DATE (DD-MM-YYYY) July 2004
2. REPORT TYPE
Final report

4. TITLE AND SUBTITLE

Navigation Study for Arthur Kill 50-ft Channel Improvements, New York Harbor

6. AUTHOR(S)

Dennis W. Webb

\section{PERFORMING ORGANIZATION NAME(S) AND ADDRESS(ES)}

U.S. Army Engineer Research and Development Center

Coastal and Hydraulics Laboratory

3909 Halls Ferry Road

Vicksburg, MS 39180-6199

\section{SPONSORING I MONITORING AGENCY NAME(S) AND ADDRESS(ES)}

U.S. Army Engineer District, New York

Jacob K. Javits Federal Building

26 Federal Plaza, Room 2109

New York, NY 10278-0090

\section{DISTRIBUTION / AVAILABILITY STATEMENT}

Approved for public release; distribution is unlimited.

\section{SUPPLEMENTARY NOTES}

\section{ABSTRACT}

The Arthur Kill Channel is a 13.2-mile segment of the New York and New Jersey Channels along the west side of Staten Island. The reach under consideration for this study extends from Newark Bay to Howland Hook marine terminal, and includes the North of Shooters Island and Elizabethport Reaches. The proposed improvements for this study include deepening of these reaches of the Arthur Kill to $-50 \mathrm{ft}$ mlw to accommodate the post panamax container vessels expected at Howland Hook. Minor widening for the channel alignment was also considered. To evaluate these improvements a real-time ship simulation study was undertaken. Simulation models were developed for both Arthur Kill's present and future conditions. Pilots from New York Harbor operated the simulator as they would in real-life. Based upon these simulations, a final improved channel was developed.

\section{SUBJECT TERMS}

Container ship

New York Harbor

16. SECURITY CLASSIFICATION OF:

\begin{tabular}{|l|l|}
\hline a. REPORT & b. ABSTRACT \\
UNCLASSIFIED & UNCLASSIFIED \\
\hline
\end{tabular}

Navigation study Port Jersey

(1)

c. THIS PAGE
UNCLASSIFIED

17. LIMITATION OF ABSTRACT
Simulation study

\begin{tabular}{|c|} 
18. NUMBER \\
OF PAGES \\
\cline { 2 - 2 }
\end{tabular}

19a. NAME OF RESPONSIBLE PERSON

19b. TELEPHONE NUMBER (include area code) 